\title{
Geochemical evolution of a composite pluton: insight from major and trace element chemistry of titanite
}

\author{
Katarzyna Gros ${ }^{1}$ (D) Ewa Słaby ${ }^{1} \cdot$ Łukasz Birski $^{1} \cdot$ Gabriela Kozub-Budzyń $^{2} \cdot$ Jiří Sláma $^{3}$
}

Received: 11 July 2019 / Accepted: 25 June 2020 / Published online: 14 July 2020

(C) The Author(s) 2020

\begin{abstract}
Titanite from various rocks of the Karkonosze granitoid pluton (South-Eastern Poland) was studied, in order to evaluate its precision in recording magma evolution processes. The rocks are of lamprophyric, dioritic, granodioritic and granitic composition, including hybrid structures such as microgranular magmatic enclaves and composite dykes. Based on textures, chemistry and $\mathrm{Zr}$-in-titanite geothermometry, titanites can be divided into magmatic and post-magmatic populations. Late- to postmagmatic titanite is present in almost all rock types, especially in the most evolved ones (where magmatic titanite is absent) and can be characterized by low trace element and high $\mathrm{Al}$ and $\mathrm{F}$ contents. Magmatic titanite crystallized in temperatures between 610 and $870{ }^{\circ} \mathrm{C}$, after apatite and relatively simultaneously with amphibole and zircon. Titanite from lamprophyre exhibits compositional features typical of titanites formed in mafic rocks: low $\mathrm{Al}$ and $\mathrm{F}$, high $\mathrm{Ti}^{4+} /\left(\mathrm{Al}+\mathrm{Fe}^{3+}\right)$, LREE (light rare earth elemet)-enriched chondrite-normalized REE patterns, low $\mathrm{Y} / \mathrm{Zr}, \mathrm{Nb} / \mathrm{Zr}, \mathrm{Lu} / \mathrm{Hf}$, high $(\mathrm{Ce}+\mathrm{Nd}) / \mathrm{Y}, \mathrm{Th} / \mathrm{U}$ and $\mathrm{Zr}$. Titanite from hybrid rocks inherited these characteristics, indicating major contribution of the mantle-derived magma especially during early stages of magmatic evolution. Titanite compositional variations, as well as a wide range of crystallization temperatures in hybrid granodiorites point to prolonged crystallization from distinct magma domains of variable mafic versus felsic melt proportions. The extent of compositional variations decreases through subsequent stages of magmatic evolution, and titanite with the least contribution of the mafic component is characterized by higher total REE, Al and $\mathrm{F}$ contents, lower $\mathrm{Ti}^{4+} /\left(\mathrm{Al}+\mathrm{Fe}^{3+}\right),(\mathrm{Ce}+\mathrm{Nd}) / \mathrm{Y}$ and $\mathrm{Th} / \mathrm{U}$ ratios, LREE-depleted chondrite-normalized REE patterns and higher $\mathrm{Y} / \mathrm{Zr}, \mathrm{Nb} / \mathrm{Zr}$ and Lu/Hf ratios. Titanite composition from the intermediate and late stage hybrids bears signature of decreasing amount of the mafic melt and higher degree of its evolution, however, the exact distinction between the former and the latter is very limited.
\end{abstract}

Keywords Titanite $\cdot$ Rare earth elements $\cdot$ High field strength elements $\cdot$ Magma evolution $\cdot$ Magma mixing

Editorial handling: X. Xu

Electronic supplementary material The online version of this article (https://doi.org/10.1007/s00710-020-00715-x) contains supplementary material, which is available to authorized users.

Katarzyna Gros

klisowiec@twarda.pan.p1

1 Institute of Geological Sciences, Polish Academy of Sciences, Twarda 51/55, 00-818 Warsaw, Poland

2 Faculty of Geology, Geophysics and Environmental Protection, AGH University of Science and Technology, al. A. Mickiewicza 30, PL-30059 Krakow, Poland

3 Institute of Geology of the Czech Academy of Sciences, Rozvojová 2696 - Lysolaje, 16500 Praha, Czech Republic

\section{Introduction}

Titanite $\left(\mathrm{CaTiSiO}_{5}\right)$ is one of the main accessory minerals in granitoid rocks and provides a robust record of magma evolution processes. It contains two groups of elements - REE and HFSE (high-field-strength elements) -that are important tracers of a wide range of petrogenetic processes and magma sources. Along with other accessory minerals, titanite controls REE and HFSE budget in the entire magmatic system. It may crystallize over a wide range of compositions - from mafic to felsic and is sensitive to changes in oxygen fugacity $\left(f \mathrm{O}_{2}\right)$, temperature, pressure, crystal composition and melt composition (e.g. Green and Pearson 1986; Tiepolo et al. 2002; Prowatke and Klemme 2005, 2006; Piccoli et al. 2000; Hayden et al. 2008). It is also characterized by slow diffusion of trace elements (Piccoli et al. 2000), preserving the primary chemical signature of growing crystal domains. Thus, 
elemental variations in titanite may serve as useful petrogenetic indicators, unravelling otherwise hidden details of the magmatic evolution (Tiepolo et al. 2002; Bruand et al. 2014; Piccoli et al. 2000; Frost et al. 2000; Xu et al. 2015; Hu et al. 2017; Jiang et al. 2016; Laurent et al. 2017; Xie et al. 2010, 2018). Crystal zoning usually exhibited by titanite in various forms - oscillatory, core-mantle-rim, patchy, sector, can be used to decipher complex crystallization histories (e.g. McLeod et al. 2011; Hu et al. 2017; Jiang et al. 2016). Due to the capability of recording even subtle changes in magmatic environment, titanite has been widely used in the studies of magmatic systems formed by mixing of melts of various origin and composition (e.g. McLeod et al. 2011; Jiang et al. 2016; Xie et al. 2018; Hu et al. 2017; Laurent et al. 2017). Trace element ratios in titanite commonly used in these studies as magma composition/source discriminators are $(\mathrm{Ce}+\mathrm{Nd})$ / $\mathrm{Y}, \mathrm{Y} / \mathrm{Zr}, \mathrm{Nb} / \mathrm{Zr}, \mathrm{Th} / \mathrm{U}, \mathrm{Nb} / \mathrm{Ta}, \mathrm{La} / \mathrm{Ce}$ and $\mathrm{Lu} / \mathrm{Hf}$. Zr content is used as a geothemometer as $\mathrm{Zr}$ incorporation is temperature sensitive (Hayden et al. 2008). Major elements and their ratios in titanite may also point to dominating origin of participating magmas. $\mathrm{Ti}^{4+} /\left(\mathrm{Al}+\mathrm{Fe}^{3+}\right)$ ratio is indicative of mantle versus crustal origin (Piuzana et al. 2008), while $\mathrm{Al} / \mathrm{Fe}$ ratio can distinguish magmatic from hydrothermal/metamorphic titanite (Cao et al. 2015; Rasmussen et al. 2013).

Most of the studies of titanite concentrate on several rock varieties where magma mixing is most visible. From the existing literature only McLeod et al. (2011) compared titanite from various rock types of a composite pluton (the Ross of Mull granite, Scotland), involving granites, enclaves and sheets of intermediate dioritic to felsic granitic composition, formed by mixing of magmas extracted from distinct sources. Titanite from each of these varieties demonstrated slightly different compositional patterns. Our study is aimed at a significantly more complex system with a wider compositional range - from mafic lamprophyric to felsic granitic rocks, magmas derived from two distinct magma sources - mantle and lower crust, multi-stage character with decreasing intensity of mixing from the early to the late stage, different mixing structures and traces of extensive post-magmatic fluid-aided interaction. Such system is represented by the post-collisional granitoid pluton of Karkonosze (SE Poland, NE Czech Republic). Mantle-derived lamprophyric melts occasionally mixed with the lower crust-derived granitic magma, forming intermediate rocks of hybrid origin (granodiorites and quartz-diorites), granites containing more or less abundant microgranular magmatic enclaves and irregular and discontinuous composite dykes, intruding the granite of pure crustal origin (e.g. Słaby and Götze 2004; Słaby and Martin 2008). Each of these rocks are characterized not only by different intensity of the mixing process and proportions of mafic versus felsic magma, but also distinct level of magma evolution, as each melt evolved independently by fractional crystallization. So far, two minerals from the Karkonosze pluton have been studied in terms of magma evolution processes - feldspar and apatite. Presence of plagioclase rims, plagioclase inclusions and dissolution-regrowth textures gave evidence of subsequent pulses of mafic magma (Słaby et al. 2002). The proportions of mafic versus felsic melt were variable, even in the scale of a single mineral, which is not detected from the whole-rock geochemistry. However, the trace elements analysed in feldspar involved only Ba and LREE. Apatite, demonstrating complex zonation patterns and major compositional variations, provided additional data on melt heterogeneity, however, the chemical record is most informative in case of early mixing stages (Lisowiec et al. 2015).

Present study focuses on titanite, which can potentially provide more detailed data on the evolution processes. The goal is to answer several questions: 1) is titanite sensitive enough to distinguish not only between magmatic and postmagmatic stages, but also between individual magmatic episodes, 2) can titanite record varying proportions of mafic and felsic melts in different hybrid rocks and to what extent, and 3) can titanite differentiate between magma mixing and fractional crystallization processes. The combination of major, trace elements and $\mathrm{F}$ content of titanite, as well as its crystallization temperature (in relation to apatite, zircon and amphibole) helps to define petrogenetic processes and evolution of titanite chemistry during subsequent magmatic stages. Fluorine content of titanite is confronted will calculated $\mathrm{F}$ content of the melt (on the basis of apatite and biotite).

\section{Geological setting and sample description}

The post-collisional granitoid pluton of Karkonosze is situated on the NE margin of the Bohemian Massif (Fig. 1) and intruded the Saxothuringian Zone in the Late Carboniferous in transpressional/transtensional tectonic setting (Mazur and Aleksandrowski 2001). It formed by a multi-stage emplacement of several magma batches (Słaby and Martin 2008; Žák et al. 2013). The pluton has been extensively dated by various methods and the ages show large inconsistencies. The most recent age data was reported by Kryza et al. (2014) and Kusiak et al. (2014). The former dated zircons from several rock varieties from the pluton by ID-TIMS technique to $\sim 312 \mathrm{Ma}$, concluding that the pluton was emplaced in a rather short period of time. On the other hand, Kusiak et al. (2014) performed zircon and monazite dating of several spatially spread samples, obtaining a wide range of ages, from $318 \pm 6$ to 302 $\pm 4 \mathrm{Ma}$, indicating that the thermal episode of Karkonosze may have lasted $\sim 15 \mathrm{Ma}$.

The main magmatic body consists of a peraluminous, Krich calc-alkaline granite (KCG) following the classification of Barbarin (1999). Several granite varieties can be distinguished: the most common, variably evolved porphyritic granite, less common quartz-diorites and granodiorites and 


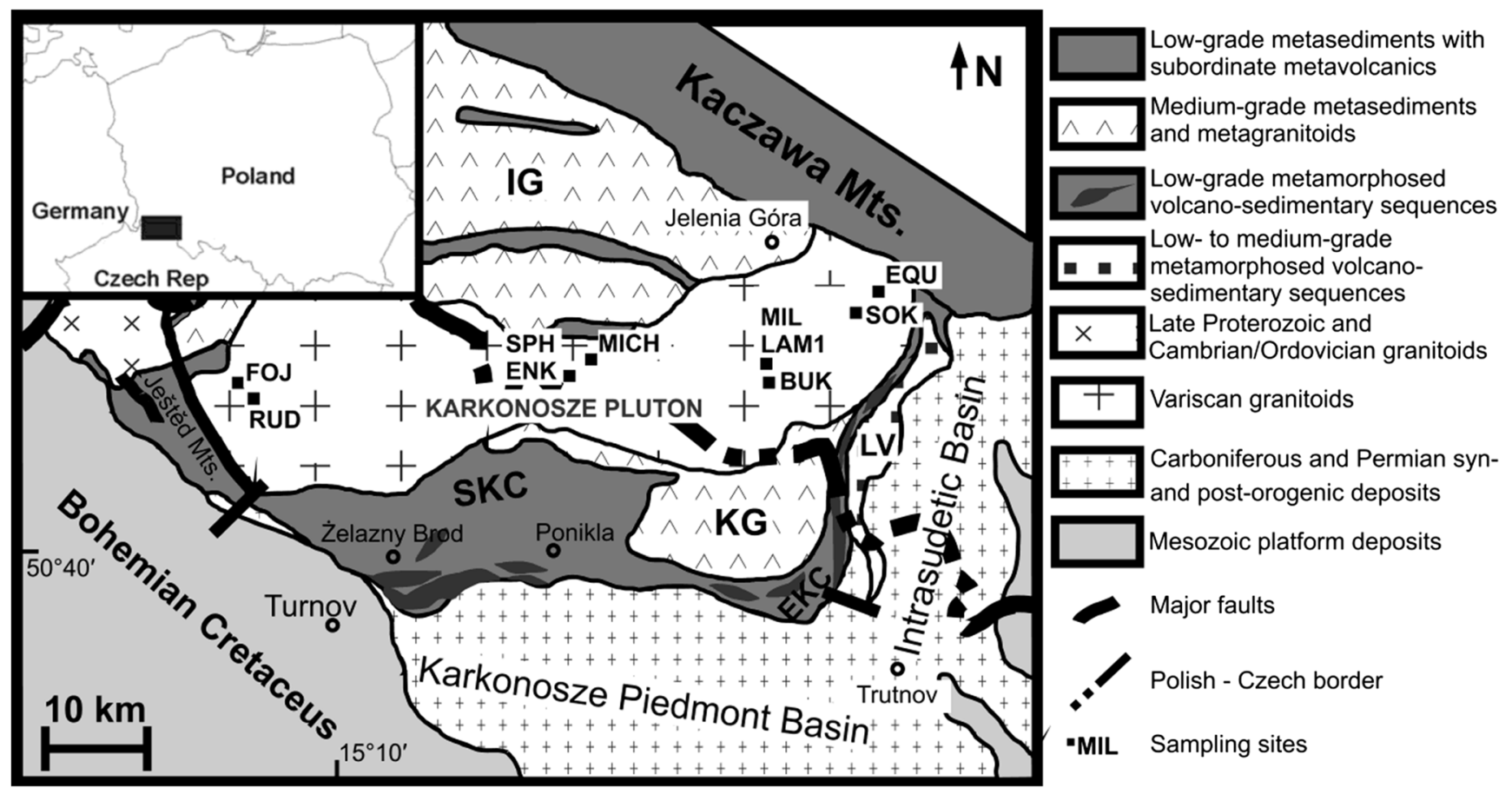

Fig. 1 Simplified geological map of the study area (modified after Patočka et al. 2000). IG - Izera gneisses and granito-gneisses with belts of mica schists; EKC - Eastern Karkonosze Complex; LV - Leszczyniec

equigranular granite. Moreover, the pluton contains numerous microgranular magmatic enclaves, MME (enclosed mainly in porphyritic granite), as well as composite, leucocratic and lamprophyric dykes. Selected macrotextures of the hybrid rocks are shown in Fig.2. South-western margin of the batholith is composed of the oldest, S-type, crustally-derived twomica equigranular granite (Tanvald granite), which evolved separately from the remaining rocks.

The petrological and geochemical evolution of the pluton has been extensively studied using whole-rock and mineral chemistry (Słaby and Götze 2004; Awdankiewicz et al. 2005; Słaby and Martin 2005; Awdankiewicz 2007; Słaby et al. 2007a, 2007b, 2008; Słaby and Martin 2008; Lisowiec et al. unit; SKC - Southern Karkonosze Complex. Geographical coordinates of the sampling sites are given in Lisowiec et al. (2015)

2015). One of the main differentiation mechanisms responsible for the compositional diversity is mixing between mantlederived lamprophyric melt and crust-derived granitic magma. The chemical and isotopic composition of the mantle-related rocks points to a metasomatized mantle source enriched in LILE (lithophile large-ion elements) (Słaby and Martin 2005). The two distinct melts, being in the course of independent evolution by fractional crystallization, interacted with each other during subsequent stages of magmatic evolution. The evolution can be divided into three main stages. The early stage was dominated by intensive mixing of yet poorly crystallized and hot magmas, giving rise to more or less homogenous quartzdiorites and granodiorites (Fig. 2a). In the following stages, the

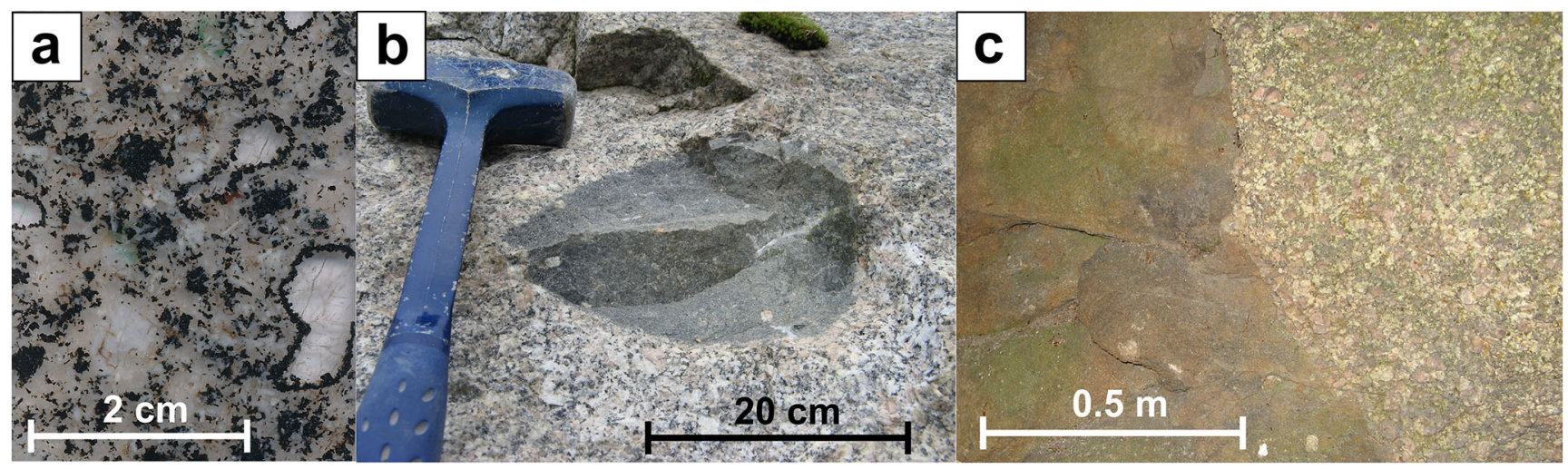

Fig. 2 Rock textures of selected hybrid samples. a Thin-section of FOJ with visible ocelli texture and biotite-amphibole clots. b Rounded microgranular magmatic enclave enclosed in porphyritic granite. c Contact between the composite dyke SOK and the surrounding equigranular granite 
mafic magma was injected in smaller quantities into slightly more viscous granitic magma and formed less evolved porphyritic granites with minor mafic enclaves. Late stage of mixing is represented by the presence of abundant magmatic enclaves (Fig. 2b), that strongly interacted with the surrounding crystalrich host, composite dykes, which intruded the partially consolidated granite and formed irregular, discontinuous bodies of varying composition, and highly evolved porphyritic and equigranular granite. The interaction between the composite dykes and the granite is visible only along the boundaries (Fig. 2c). Lamprophyric dykes are the youngest and intruded the already fully crystallized granite directly from the mantle. Whereas the lamprophyre dykes represent the mantle endmember of the mixing system, the equigranular granite is the equivalent of the pure and evolved crust-derived magma. The magma mixing process is recorded not only in macro-scale (enclaves, composite dykes, intermediate rocks) but also in micro-scale, resulting in complex growth textures in single minerals, mostly alkali feldspar and apatite. Different trace element composition between adjacent zones and distinct CL characteristics (caused by different density of structural defects, e.g. trace element impurities) of feldspars and apatites from porphyritic granites and granodiorites suggest changing crystallization environment due to magma hybridization (Słaby and Götze 2004; Lisowiec et al. 2015). The evolution of apatite composition from early to late stages of magmatic history also strongly points to changing proportions of mafic versus felsic melts and progressive homogenization of the magmatic system (Lisowiec et al. 2015).

The samples from this study cover all three stages of the magmatic evolution of the Karkonosze pluton. Their chemical composition is described in detail in Staby and Martin (2008) and Awdankiewicz (2007). The most important petrographic and mineralogical characteristics are summarized in Table 1. Lamprophyres cannot be assigned to a particular stage, as even though they are one of the youngest structures in the pluton, their composition represents the primitive mantle-derived melt. Therefore, they are considered simply as the pure mafic mantlederived end-member. Two lamprophyre samples were used: LAM1 and LAM2 (take from two different lamprophyric dykes), with silica content of $\sim 58$ and $\sim 53 \mathrm{wt} \%$, respectively. Chondrite-normalized REE patterns are LREE-enriched with negative Eu anomaly. It is important to note that LAM1 sample is located on the mantle-related end of the whole-rock mixing trend, whereas LAM2 is positioned slightly outside of the trend (suggesting that it does not entirely represents the mantle endmember participating in the mixing process).

The early stage is represented by two granodiorite samples FOJ and RUD. FOJ is homogenous in terms of texture and less evolved ( $\sim 63 \mathrm{wt} \% \mathrm{SiO}_{2}$ ), whereas RUD is strongly heterogeneous and more evolved $\left(\sim 69 \mathrm{wt} \%\right.$ of $\left.\mathrm{SiO}_{2}\right)$. Chondritenormalized REE patterns are LREE-enriched, with a small negative $\mathrm{Eu}$ anomaly.
The intermediate stage is represented by two porphyritic granites MIL and MICH. MIL is the most primitive granite with $\sim 70 \mathrm{wt} \%$ silica, whereas MICH is slightly more evolved $\left(\sim 72 \mathrm{wt} \%\right.$ of $\left.\mathrm{SiO}_{2}\right)$. MIL granite contains minor enclaves. The contribution of the mafic melt is significantly larger in MIL granite $(\sim 50 \%)$, whereas in the MICH granite it is negligible. Both granites are enriched in LILE and demonstrate LREEenriched chondrite-normalized REE patterns with strong negative $\mathrm{Eu}$ anomalies.

The late stage is represented by two enclaves - BUK and ENK, one composite dyke SOK and two granites - SPH and EQU. BUK was extracted from the EQU granite, whereas ENK was sampled from the SPH granite. The BUK enclave contains $\sim 69 \mathrm{wt} \%$ of $\mathrm{SiO}_{2}$. The chemistry of the studied ENK is unknown, however, the silica content of the enclaves hosted in SPH usually ranges between 64 and $69 \mathrm{wt} \%$ (Słaby and Martin 2008). Chondrite-normalized REE patterns of both enclaves (in case of ENK - its representatives) are LREEenriched with negative Eu anomaly, however, the LREE enrichment is significantly more pronounced in the ENK enclave, whereas Eu anomaly is stronger in the BUK enclave. Composite dyke SOK cuts equigranular granite and contains $\sim 68 \mathrm{wt} \% \mathrm{SiO}_{2}$. Chondrite-normalized REE pattern is LREEenriched, however compared to the MME, LREE concentrations are significantly higher. Porphyritic granite SPH is one of the most evolved granite varieties, with silica content of $77 \mathrm{wt} \%$. It contains abundant MMEs, however, the contribution of the mafic melt in the granite itself is the lowest among all porphyritic granites. Equigranular granite $\mathrm{EQU}$ is the mostevolved granite variety $\left(\sim 78 \mathrm{wt} \% \mathrm{SiO}_{2}\right)$. Chondritenormalized REE patterns are slightly less LREE-enriched compared to porphyritic granite. This sample is considered as the pure crust-derived end-member of the magmatic evolution of the Karkonosze granitoid pluton.

\section{Analytical techniques}

Back-scattered electron (BSE) images of titanite and chemical analyses of titanite, amphibole and biotite from polished and carbon-coated thin-sections were performed using a JEOL JXA-8230 SuperProbe electron probe micro-analyzer (EPMA) equipped with five wavelength-dispersive X-ray spectrometers. Accelerating voltage, beam current and beam size were set to $15 \mathrm{kV}, 20 \mathrm{nA}$ and $5 \mu \mathrm{m}$ for mica and amphibole, and $15 \mathrm{kV}, 40 \mathrm{nA}$ and $1 \mu \mathrm{m}$, respectively, for titanite. Detailed conditions of the analyses (X-ray lines, crystals, counting times, detection limits and standards) are given in electronic supplementary material (ESM; Tables S1 and S2). Data were corrected according to the ZAF procedure using JEOL software for EPMA. Titanite formulae were calculated based on 5 oxygen atoms. Fluorine concentrations in biotite were used to calculate F contents in coexisting melt. In order 
Table 1 General description of the samples used in the study

\begin{tabular}{|c|c|c|c|c|c|c|c|c|c|}
\hline $\begin{array}{l}\text { Stage of } \\
\text { magmatic } \\
\text { evolution }\end{array}$ & Sample & $\begin{array}{l}\text { Equivalent } \\
\text { in Słaby } \\
\text { and Martin } \\
(2008)\end{array}$ & Localization & $\begin{array}{l}\text { QAPF } \\
\text { classification }\end{array}$ & $\begin{array}{l}\text { Mantle vs. } \\
\text { crust } \\
\text { contribution }\end{array}$ & Texture & $\begin{array}{l}\text { Mineralogical } \\
\text { composition }\end{array}$ & $\begin{array}{l}\mathrm{SiO}_{2} \\
{[\mathrm{wt} \%]}\end{array}$ & $\begin{array}{l}\text { Selected trace } \\
\text { element } \\
\text { characteristics }\end{array}$ \\
\hline \multirow[t]{2}{*}{$\begin{array}{l}\text { Mantle } \\
\text { end-- } \\
\text { member }\end{array}$} & LAM1 & LAM4 & Karpacz & lamprophyre & mantle & fine-grained & $\begin{array}{l}\text { plagioclase, } \\
\text { phlogopite, } \\
\text { amphibole, } \\
\text { magnetite, pyroxene, } \\
\text { olivine, titanite, } \\
\text { calcite, apatite }\end{array}$ & 58.1 & $\begin{array}{l}\text { most enriched } \\
\text { in LREE, } \\
\mathrm{Ba}, \mathrm{Sr}, \mathrm{Zr}\end{array}$ \\
\hline & LAM2 & $327 *$ & Bukowiec & lamprophyre & mantle & fine-grained & $\begin{array}{l}\text { alkali feldspar, } \\
\text { phlogopite, } \\
\text { amphibole, } \\
\text { magnetite, quartz, } \\
\text { pyroxene, olivine, } \\
\text { titanite, apatite, } \\
\text { epidote }\end{array}$ & 53.6 & \\
\hline \multirow[t]{2}{*}{ Early stage } & FOJ & HYB8 & Fojtka & granodiorite & $\begin{array}{l}\text { mantle }>* * \\
\text { crust }\end{array}$ & $\begin{array}{l}\text { fine-grained, } \\
\text { equigranular, } \\
\text { homogenous }\end{array}$ & $\begin{array}{l}\text { K-feldspar, } \\
\text { plagioclase, quartz, } \\
\text { amphibole, biotite, } \\
\text { apatite, zircon, } \\
\text { titanite, magnetite, } \\
\text { ilmenite, rutile }\end{array}$ & 63.4 & $\begin{array}{l}\text { enriched in } \\
\text { LREE, Ba, } \\
\mathrm{Zr}\end{array}$ \\
\hline & RUD & HYB10 & Rudolfov & granodiortie & mantle $>$ crust & $\begin{array}{l}\text { porphyritic, } \\
\text { heterogeneous, } \\
\text { with abundant } \\
\text { enclaves }\end{array}$ & $\begin{array}{l}\text { K-feldspar, } \\
\text { plagioclase, quartz, } \\
\text { amphibole, biotite, } \\
\text { apatite, zircon, } \\
\text { titanite, magnetite, } \\
\text { thorite, allanite, } \\
\text { rutile }\end{array}$ & 69.2 & $\begin{array}{l}\text { enriched in } \\
\text { LREE, Ba, } \\
\text { Y, Th }\end{array}$ \\
\hline \multirow[t]{2}{*}{$\begin{array}{l}\text { Middle } \\
\text { stage }\end{array}$} & MIL & POR6 & Miłków & granite & mantle $=$ crust & $\begin{array}{l}\text { porphyritic, with } \\
\text { minor enclaves }\end{array}$ & $\begin{array}{l}\text { K-feldspar megacrysts, } \\
\text { matrix: } \\
\text { alkali-feldspar, } \\
\text { plagioclase, quartz, } \\
\text { biotite, amphibole, } \\
\text { apatite, zircon, } \\
\text { allanite, titanite, } \\
\text { magnetite, ilmenite, } \\
\text { scheelite, thorite, } \\
\text { rutile }\end{array}$ & 70.1 & $\begin{array}{l}\text { enriched in } \\
\text { LREE, Ba, } \\
\text { Zr, Y }\end{array}$ \\
\hline & $\mathrm{MICH}$ & POR10 & Michałowice & granite & $\begin{array}{c}\text { mantle }<< \\
\text { crust }\end{array}$ & porphyritic & $\begin{array}{l}\text { K-feldspar megacrysts, } \\
\text { matrix: } \\
\text { alkali-feldspar, } \\
\text { plagioclase, quartz, } \\
\text { biotite, apatite, } \\
\text { zircon, allanite, } \\
\text { titanite, magnetite, } \\
\text { ilmenite, scheelite, } \\
\text { thorite, monazite, } \\
\text { rutile }\end{array}$ & 71.8 & $\begin{array}{l}\text { enriched in } \\
\text { LREE, Ba, } \\
\text { Zr, Y, Th }\end{array}$ \\
\hline \multirow[t]{2}{*}{ Late stage } & SPH & POR26 & $\begin{array}{l}\text { Szklarska } \\
\text { Poręba-H- } \\
\text { uta }\end{array}$ & granite & $\begin{array}{c}\text { mantle }<<< \\
\text { crust }\end{array}$ & $\begin{array}{l}\text { porphyritic, with } \\
\text { abundant } \\
\text { enclaves }\end{array}$ & $\begin{array}{l}\text { K-feldspar megacrysts, } \\
\text { matrix: } \\
\text { alkali-feldspar, } \\
\text { plagioclase, quartz, } \\
\text { biotite, apatite, } \\
\text { zircon, allanite, } \\
\text { titanite, magnetite, } \\
\text { ilmenite, scheelite, } \\
\text { thorite, rutile, } \\
\text { monazite }\end{array}$ & 77.5 & $\begin{array}{l}\text { depleted in } \\
\text { LREE } \\
\text { (compared } \\
\text { to other } \\
\text { samples) } \\
\text { enriched in } \\
\text { Pb, Th }\end{array}$ \\
\hline & BUK & MME6 & Bukówka & $\begin{array}{l}\text { granodioritic } \\
\text { enclave }\end{array}$ & $\begin{array}{l}\text { mantle } \\
\qquad>\text { crust }\end{array}$ & $\begin{array}{l}\text { fine-grained, } \\
\text { slightly } \\
\text { heterogeneous, }\end{array}$ & $\begin{array}{l}\text { plagioclase, } \\
\text { alkali-feldspar, } \\
\text { biotite, amphibole, }\end{array}$ & 69.8 & $\begin{array}{l}\text { enriched in } \\
\mathrm{Rb}, \mathrm{Zr}, \mathrm{Y}, \\
\mathrm{Ba}\end{array}$ \\
\hline
\end{tabular}


Table 1 (continued)

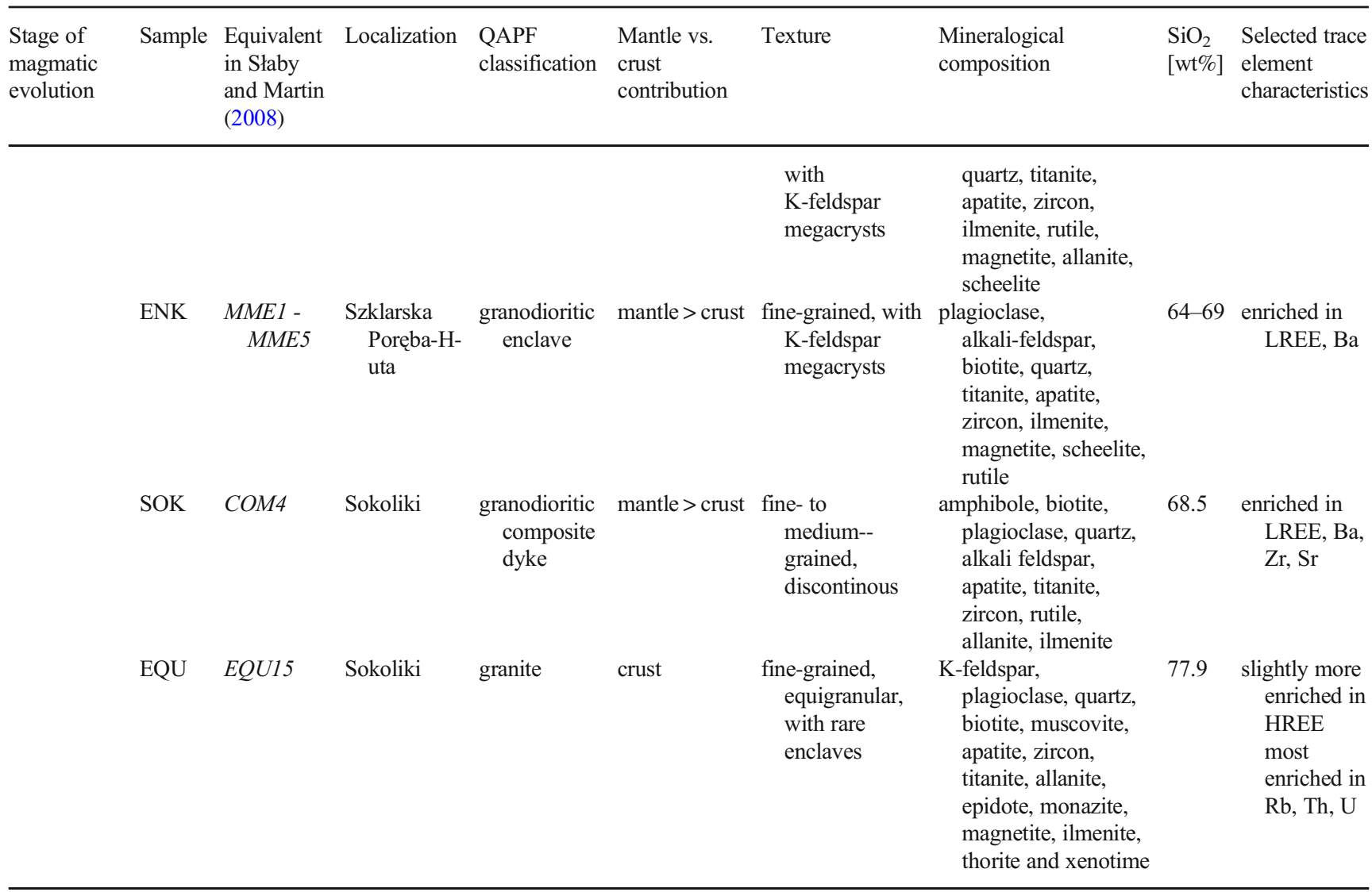

*Sample number from Awdankiewicz (2007)

$* *$ '='comparable contribution, '<'slightly smaller contribution, '<<'- significantly smaller contribution, '<<<'negligible contribution

to limit the potential migration of $\mathrm{F}$, it was measured in the beginning of each analysis.

A Thermo Scientific Element 2 high-resolution sector field ICP-MS coupled to a $193 \mathrm{~nm}$ ArF excimer laser (Teledyne Cetac Analyte Excite laser) was used to acquire the titanite trace element (TE) data at the Institute of Geology of the Czech Academy of Sciences. The laser was fired at a repetition rate of $10 \mathrm{~Hz}$ and fluence of $3.4 \mathrm{~J} / \mathrm{cm}^{2}$ with $30 \mu \mathrm{m}$ laser spot size. Helium carrier gas was flushed through the twovolume ablation cell at a flow rate of $0.7 \mathrm{~L} / \mathrm{min}$ and mixed with $0.8 \mathrm{~L} / \mathrm{min} \mathrm{Ar}$ and $0.004 \mathrm{~L} / \mathrm{min} \mathrm{N}$ prior to introduction into the ICP. The in-house glass signal homogenizer (design of Tunheng and Hirata 2004) was used for mixing all the gases and aerosol resulting in smooth, spike-free signal. The signal was tuned for maximum sensitivity while keeping low oxide level, commonly below $0.1 \%$. Typical acquisitions consisted of $15 \mathrm{~s}$ of blank measurement followed by measurement of trace element signals from the ablated materials for another $20 \mathrm{~s}$ with $30 \mathrm{~s}$ of wash time between each analysis. This ablation pattern was repeated on each analytical spots with first ablation being used for collection of data at the low mass resolution mode $\left(\mathrm{m} / \Delta \mathrm{m}=300:{ }^{25} \mathrm{Mg},{ }^{27} \mathrm{Al},{ }^{29} \mathrm{Si},{ }^{43} \mathrm{Ca},{ }^{57} \mathrm{Fe}\right.$,
${ }^{88} \mathrm{Sr},{ }^{89} \mathrm{Y},{ }^{90} \mathrm{Zr},{ }^{93} \mathrm{Nb},{ }^{18} \mathrm{Sn},{ }^{137} \mathrm{Ba},{ }^{139} \mathrm{La},{ }^{140} \mathrm{Ce},{ }^{141} \mathrm{Pr},{ }^{146} \mathrm{Nd}$, ${ }^{147} \mathrm{Sm},{ }^{153} \mathrm{Eu},{ }^{157} \mathrm{Gd},{ }^{159} \mathrm{~Tb},{ }^{163} \mathrm{Dy},{ }^{165} \mathrm{Ho},{ }^{166} \mathrm{Er},{ }^{169} \mathrm{Tm}$, ${ }^{172} \mathrm{Yb},{ }^{175} \mathrm{Lu},{ }^{178} \mathrm{Hf},{ }^{181} \mathrm{Ta},{ }^{232} \mathrm{Th}$ and $\left.{ }^{238} \mathrm{U}\right)$ and the second ablation for collection of data at the medium mass resolution mode $\left(\mathrm{m} / \Delta \mathrm{m}=4000:{ }^{24} \mathrm{Mg},{ }^{27} \mathrm{Al}\right.$ and $\left.{ }^{56} \mathrm{Fe}\right)$. The measurement sequence consisted of the repeated blocks of two analyses of NIST SRM612, one analysis of BCR-2 standard and 10 unknowns. Trace element data were calibrated against the NIST SRM612 glass (Pearce et al. 1997) using the ${ }^{43} \mathrm{Ca}$ as internal standard together with concentration values of the unknown samples obtained from EMPA analysis.

The minimum detection limit values were calculated by multiplying the variance of the background by 3.25 for individual elements and are listed in the data table. The time-resolved signal data were processed using the Glitter software (van Achterbergh et al. 2001). The precision of the analyses (1 RSD) ranges between 5 and $15 \%$ for most elements. The accuracy was monitored by a homogenized basalt reference material BCR-2 (Raczek et al. 2001). The models used for temperature, pressure and F-in-melt calculations (Watson and Harrison 1983; Harrison and Watson 1984; Icenhower and 
London 1997; Hayden et al. 2008; Webster et al. 2009; Pasero et al. 2010; Ridolfi et al. 2010) are described in detail in the ESM (Table S1).

\section{Results}

\section{Internal textures of titanite}

Titanite from lamprophyres exhibits distinct textural features between the two studied samples. LAM1 titanite occurs as small $(<50 \mu \mathrm{m})$, anhedral grains intergrown with biotite (or replacing it), epidote, amphibole and pyroxene. It exhibits homogenous or porous textures and frayed rims. Some crystals are also associated with magnetite. LAM2 titanite, on the other hand, forms large euhedral to subhedral crystals associated mostly with amphibole and chlorite (Fig. 3a). The grains are either relatively homogenous or demonstrate regular, oscillatory zoning (rarely sector zoning) and contain numerous magnetite and apatite inclusions (Fig. 3a).

Titanite from granodiorites (FOJ and RUD) occurs either as large, euhedral to subhedral grains, interstitial grains growing between feldspar, biotite and amphibole or anhedral grains attached to or growing in biotite. Individual euhedral/ subhedral grains exhibit usually sector, oscillatory or fir-tree zoning (Fig. 3c), whereas interstitial and anhedral grains demonstrate sector or slightly patchy zonation patterns and often contain ilmenite inclusions (Fig. 3b). Some grains display BSE-darker rims, which are usually on the titanite-biotite border and show distinct major and trace element composition.

The porphyritic granites MIL and MICH contain mostly titanite forming larger euhedral to subhedral grains or rarely anhedral grains grown in or intergrown with biotite. The former displays sector, oscillatory, fir-tree or slightly patchy zoning (Fig. 3de), whereas the latter is either homogenous or demonstrate sector to patchy zoning. Patchy zoning in large euhedral grains is concentrated along fractures and is more common for $\mathrm{MICH}$ titanites. Anhedral grains associated with biotite are homogenous or exhibit sector to patchy zoning. Many crystals (mostly MICH) often contain BSE-darker rims (of significantly distinct composition) and ilmenite/magnetite inclusions (Fig. 3e). One MICH grain of distinct chemical composition is interstitial, mostly BSE-dark and exhibits sector to patchy zonation.

Enclave BUK contains two types of titanite: one occurring as large sub- to anhedral, strongly zoned (oscillatory, sector or patchy zoning) grains mostly associated with biotite and containing ilmenite and apatite inclusions (Fig. 3f) and the second that forms smaller subhedral, individual crystals (growing in feldspar and rarely associated with biotite) demonstrating sector or patchy zoning and apatite inclusions. These two types are compositionally distinct. Titanite from the enclave ENK occurs only as small subhedral to anhedral grains intergrown with (or growing in) biotite (Fig. 3g). The crystals are mostly homogenous or display weak sector zoning.

The composite dyke SOK contains titanite forming larger anhedral or subhedral (and sometimes interstitial) grains mostly associated with biotite (Fig. 3h). It exhibits sector zoning in the interior and often are surrounded by BSE-darker rims. The most evolved porphyritic granite SPH contains only small titanite grains growing in or intergrown with biotite. Mostly titanite occurs in biotite+chlorite+epidote+titanite assemblage. The crystals are either homogenous or display patchy zoning and contain apatite or ilmenite inclusions. Titanite from the granite EQU occurs as small anhedral and homogenous grains growing in biotite, which is often almost entirely chloritized. Sometimes the shape of titanite crystals mimics that of the chlorite substituting biotite.

\section{P-T conditions and F content of the melt}

Temperature of crystallization was calculated based on four models - apatite saturation temperature (AST), zircon saturation temperature (TZr), Zr-in-titanite and amphibole (Amp TB spreadsheet developed by Ridolfi et al. 2010) - in order to constrain the relative timing of titanite crystallization and its relation to other minerals. The summary of calculated temperatures is given in Table 2 .

Almost all samples yielded very high temperatures of apatite saturation $>920^{\circ} \mathrm{C}$, with the highest value for LAM2 and FOJ $\left(1069^{\circ} \mathrm{C}\right.$ and $1005^{\circ} \mathrm{C}$, respectively). Samples ENK and $\mathrm{MICH}$ provided temperatures 987 and $970{ }^{\circ} \mathrm{C}$, respectively. Temperatures for LAM1, RUD, MIL, BUK and SOK are between 925 and $945{ }^{\circ} \mathrm{C}$. The lowest values were calculated for EQU and SPH $-870{ }^{\circ} \mathrm{C}$ and $785^{\circ} \mathrm{C}$, respectively. Only the value calculated for SPH granite is outside of the temperature range dedicated for the application of the model (850 $1500^{\circ} \mathrm{C}$, Harrison and Watson 1984).

Zircon saturation temperatures are the lowest for lamprophyres $\left(723-732{ }^{\circ} \mathrm{C}\right)$ and the most evolved granites SPH and EQU (692 and $721{ }^{\circ} \mathrm{C}$, respectively). Whereas in case of lamprophyres, the whole-rock chemistry is responsible for delayed onset of zircon crystallization (as lamprophyres are rich in Zr, Słaby and Martin 2008), low TZr values for the evolved granites are caused by the lowest $\mathrm{Zr}$ content among all granite varieties of the pluton (Słaby and Martin 2008). The highest $\mathrm{TZr}$ was calculated for granodiorite FOJ, enclaves including BUK and SOK composite dyke $\left(>800{ }^{\circ} \mathrm{C}\right)$. The remaining samples - RUD, MIL and $\mathrm{MICH}$ demonstrate intermediate $\mathrm{TZr}$ values, ranging from 750 to $790{ }^{\circ} \mathrm{C}$.

Temperature of amphibole crystallization was calculated for samples LAM1, FOJ, RUD, MIL and SOK. Chemical composition of amphiboles is given in the ESM (Table S3). LAM1 amphiboles yielded the highest and narrow temperature range: $930-950{ }^{\circ} \mathrm{C}$. The lowest values were calculated for GRL composite dyke: $650-700^{\circ} \mathrm{C}$ (with one analysis yielding 
Fig. 3 Back-scattered electron (BSE) images of representative magmatic titanite grains from the studied samples. a Titanite grain from the LAM2 lamprophyre, showing weak oscillatory zoning. b Interstitial titanite grain from the FOJ granodiorite, showing sector/ oscillatory zoning. $\mathbf{c}$ Titanite grain from the RUD granodiorite, showing oscillatory zoning. d Titanite grain from the MIL porphyritic granite, showing combined sector/oscillatory zoning. e Titanite grain from the $\mathrm{MICH}$ porphyritic granite showing mostly oscillatory and slightly patchy zoning. f Interstitial titanite grain from BUK-2 population, showing sector zoning. g Titanite grain from ENK enclave, associated with biotite and showing slight sector zoning $\mathbf{h}$ Anhedral titanite grain from SOK composite dyke, with a zircon inclusion and sector zoning. Abbreviations of mineral names: phl - phlogopite, amp amphibole, chl - chlorite, $\mathrm{pl}$ plagioclase, bt - biotite, ilm ilmenite, fsp - feldspar, ttn titanite, zrn - zircon, mag magnetite
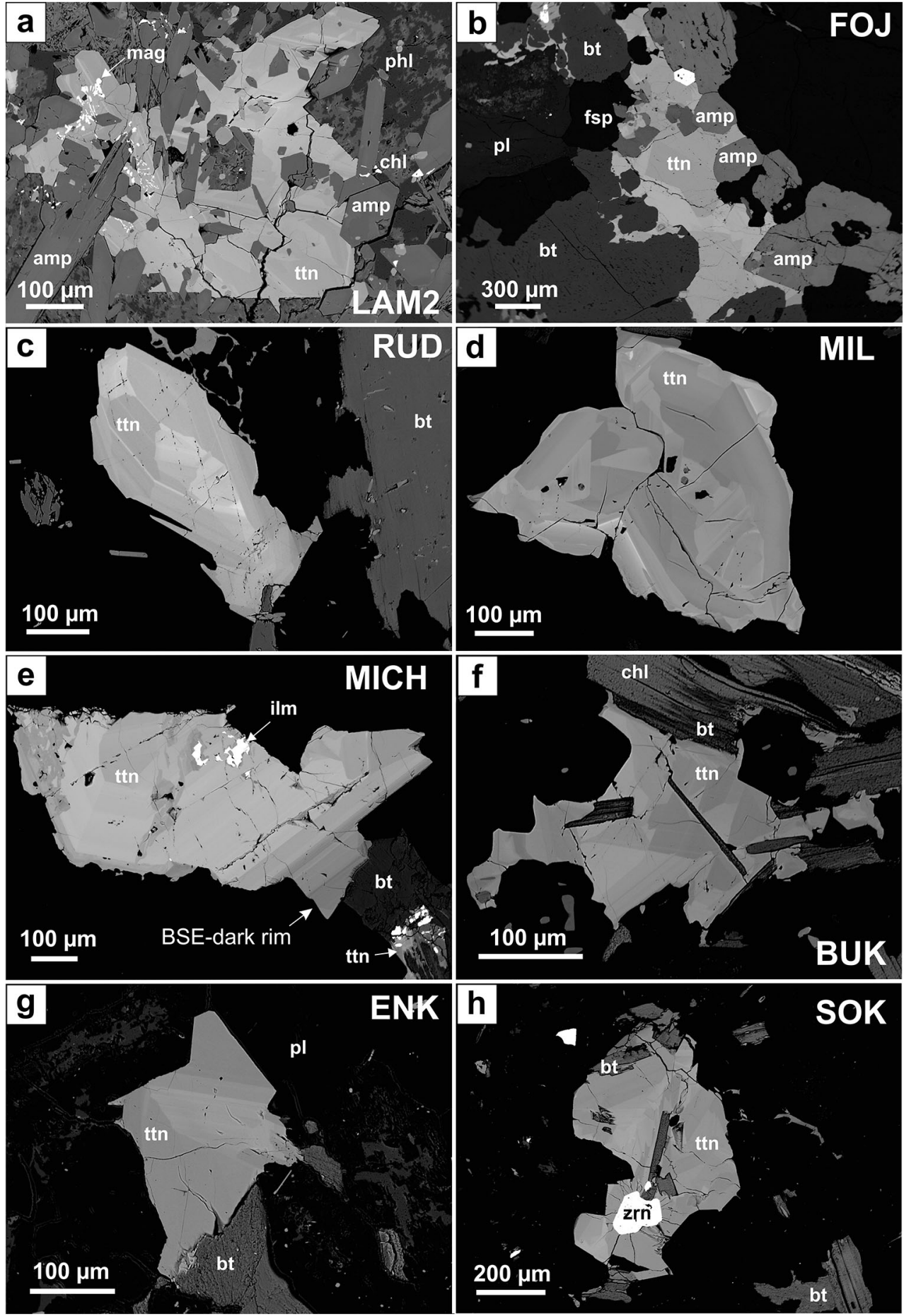

$\left.730{ }^{\circ} \mathrm{C}\right)$. SOK composite dyke provided temperatures between 750 and $830{ }^{\circ} \mathrm{C}$, whereas the remaining samples RUD, FOJ, MIL - yielded similar temperature ranges between 660 and $800^{\circ} \mathrm{C}$. As the Ridolfi et al. (2010) model was tested on temperatures $>766^{\circ} \mathrm{C}$, the lower values calculated for RUD, FOJ, MIL granites may be questionable. Pressures calculated for the samples are between 1 and $2 \mathrm{kbar}$ for SOK, $\sim 1 \mathrm{kbar}$ for FOJ, RUD, MIL and between 2.5 and 3 kbar for
LAM1. These values are mostly in good agreement with pressures calculated by Słaby and Martin (2008), except for lamprophyres and composite dykes, for which the applied geothermobarometer yielded slightly lower pressures (as opposed to 5-7 kbar and 4-6 kbar, respectively).

Zr-in-titanite temperature calculations provided relatively wide ranges for all studied samples. The highest temperatures were calculated for LAM2 titanites. $\mathrm{Zr}$ content varies from 
Table 2 Crystallization temperatures calculated from titanite, apatite, amphibole and zircon

\begin{tabular}{|c|c|c|c|c|c|c|}
\hline Sample & $\begin{array}{l}\text { Zr in titanite } \\
{[\mathrm{ppm}]}\end{array}$ & $\begin{array}{l}\mathrm{T} \text { from } \mathrm{Zr} \text {-in-titanite } \\
{\left[{ }^{\circ} \mathrm{C}\right]}\end{array}$ & $\begin{array}{l}\text { Apatite saturation } \\
\text { temperature }\left[{ }^{\circ} \mathrm{C}\right]\end{array}$ & $\begin{array}{l}\text { Temperature based on } \\
\text { Amp }-\mathrm{TB}^{*}\left[{ }^{\circ} \mathrm{C}\right]\end{array}$ & $\begin{array}{l}\mathrm{Zr} \text { in whole-rock } \\
{[\mathrm{ppm}]^{* *}}\end{array}$ & $\operatorname{TZr}\left[{ }^{\circ} \mathrm{C}\right]$ \\
\hline LAM1 & & & 925 & $934-952$ & 182 & 732 \\
\hline LAM2 & $151-6941$ & $652-873$ & 1070 & - & 505 & 723 \\
\hline FOJ & 190-3313 & $674-842$ & 1006 & $659-795$ & 371 & 812 \\
\hline RUD & $197-841$ & $676-754$ & 929 & $690-764$ & 171 & 759 \\
\hline MIL & $106-1860$ & $645-803$ & 945 & $662-783$ & 192 & 772 \\
\hline $\mathrm{MICH}$ & $48-2171$ & $610-813$ & 971 & - & 203 & 789 \\
\hline $\begin{array}{l}\text { BUK-1 } \\
\text { BUK-2 }\end{array}$ & $\begin{array}{l}267-1728 \\
55-850\end{array}$ & $\begin{array}{l}691-799 \\
616-755\end{array}$ & 936 & $\begin{array}{l}- \\
-\end{array}$ & 286 & 817 \\
\hline ENK & $0.52-287$ & $449-695$ & 987 & - & $163-321^{* * * *}$ & $769-828$ \\
\hline SOK & $48-1000$ & $610-760$ & 943 & $752-828$ & 359 & 831 \\
\hline SPH & - & - & 785 & - & 56 & 692 \\
\hline EQU & - & - & 872 & - & 87 & 721 \\
\hline
\end{tabular}

*Amp - TB is an Excel spreadsheet developed by Ridolfi et al. (2010)

**Zr whole-rock data was taken from Słaby and Martin (2008)

***Zr content and TZr calculated for various enclaves from the same host granite

150 to $6940 \mathrm{ppm}$, which translates into 650 to $870{ }^{\circ} \mathrm{C}$. Such large variation in crystallization temperature is mostly intergrain, indicating that some crystals crystallized earlier than others. However, in several cases the high temperature gradient involves single grains, in which crystal cores usually demonstrate higher temperatures (although they are not discernible in BSE images) between 780 and $870{ }^{\circ} \mathrm{C}$, whereas BSE-dark rims crystallized from slightly cooler melt (650$\left.700{ }^{\circ} \mathrm{C}\right)$. FOJ titanites exhibit slightly narrower $\mathrm{Zr}$ content and temperatures ranges: $190-3300 \mathrm{ppm}$ and $670-840{ }^{\circ} \mathrm{C}$, respectively. However, concentrations $>1000 \mathrm{ppm}$ and temperatures $>800{ }^{\circ} \mathrm{C}$ are displayed only by three growth zones, located in the grain interiors and not discernible in BSE images, except for one which is a BSE-brighter sector. The remaining grains show moderate temperature gradient in single grain scale (usually $300-900 \mathrm{ppm}$, which translates into 700$760{ }^{\circ} \mathrm{C}$ temperature difference). Interstitial grains display slightly lower $\mathrm{Zr}$ contents and crystallization temperatures ( $\sim 200-400 \mathrm{ppm}$ and $680-720^{\circ} \mathrm{C}$ ), whereas BSE-dark rims of some crystals exhibit the lowest values (190-250 ppm of $\left.\mathrm{Zr}, 670-690{ }^{\circ} \mathrm{C}\right)$. In contrast to FOJ titanites, RUD titanites demonstrate significantly narrower range of $\mathrm{Zr}$ contents and calculated temperatures: $200-840 \mathrm{ppm}$ and $680-750{ }^{\circ} \mathrm{C}$, respectively. Similar gradient is observed in single-grain scale, where temperature gradually decreases from the crystal interior to the rim (e.g. from 750 to $690^{\circ} \mathrm{C}$ ). Interestingly, calculations for interstitial grains yielded similar temperatures as for individual euhedral grains.

Temperature calculations for MIL and MICH titanites provided similar results. $\mathrm{Zr}$ contents and crystallization temperatures vary between 50 and $2170 \mathrm{ppm}$ and $610-810^{\circ} \mathrm{C}$, respectively, but only three growth zones (BSE-bright sectors in grain interiors) exhibit higher values (>1000 ppm of $\mathrm{Zr}$ and $770{ }^{\circ} \mathrm{C}$ ). The remaining results indicate limited temperature gradient in single-grain scale. BSE-dark rims present in several grains display significantly lower temperatures (610 $650{ }^{\circ} \mathrm{C}$ ). One interstitial $\mathrm{MICH}$ titanite shows a wide range of $\mathrm{Zr}$ contents and crystallization temperatures - from a $\mathrm{Zr}$ rich BSE-bright sector domain $\left(810^{\circ} \mathrm{C}\right)$ to a $\mathrm{Zr}$-poor BSEdark domain in grain exterior $\left(630^{\circ} \mathrm{C}\right)$.

The two BUK titanite populations exhibit different $\mathrm{Zr}$ contents and temperatures. The first population (large, subhedral grains) contains more $\operatorname{Zr}$ (270-1730 ppm), which yielded temperatures between 690 and $800{ }^{\circ} \mathrm{C}$, whereas the second population (smaller individual grains) is slightly $\mathrm{Zr}$-poorer (60$850 \mathrm{ppm})$ and generally crystallized in lower temperatures $\left(620-760{ }^{\circ} \mathrm{C}\right)$. Both populations demonstrate BSE-darker rims, which formed in significantly lower temperatures. The lowest $\mathrm{Zr}$ content and crystallization temperature is showed by titanites from the ENK enclave $-1-290 \mathrm{ppm}$ and 450 $700{ }^{\circ} \mathrm{C}$, respectively. Only three small subhedral grains exhibit higher temperatures, whereas the remaining $\mathrm{Zr}$-poor crystals are anhedral and associated with or grown in biotite. Only one BSE-bright sector growth zone in SOK titanites is richer in $\mathrm{Zr}$ $\left(2570 \mathrm{ppm}, 840{ }^{\circ} \mathrm{C}\right.$ ), whereas the remaining domains/grains show $\mathrm{Zr}$ contents between 50 and $940 \mathrm{ppm}$, and temperatures between 620 and $770{ }^{\circ} \mathrm{C}$. The temperature gradient may be similarly high in single-grain scale, with $\mathrm{Zr}$-rich cores/ interiors and Zr-poor BSE-dark margins.

As titanite exhibits large variations in F content, we used apatite and biotite to determine the concentration of $\mathrm{F}$ in the melt and its evolution. The chemical composition of apatites was taken from Lisowiec et al. (2015), whereas that of biotite is presented in the ESM (Table S3). The calculated F 


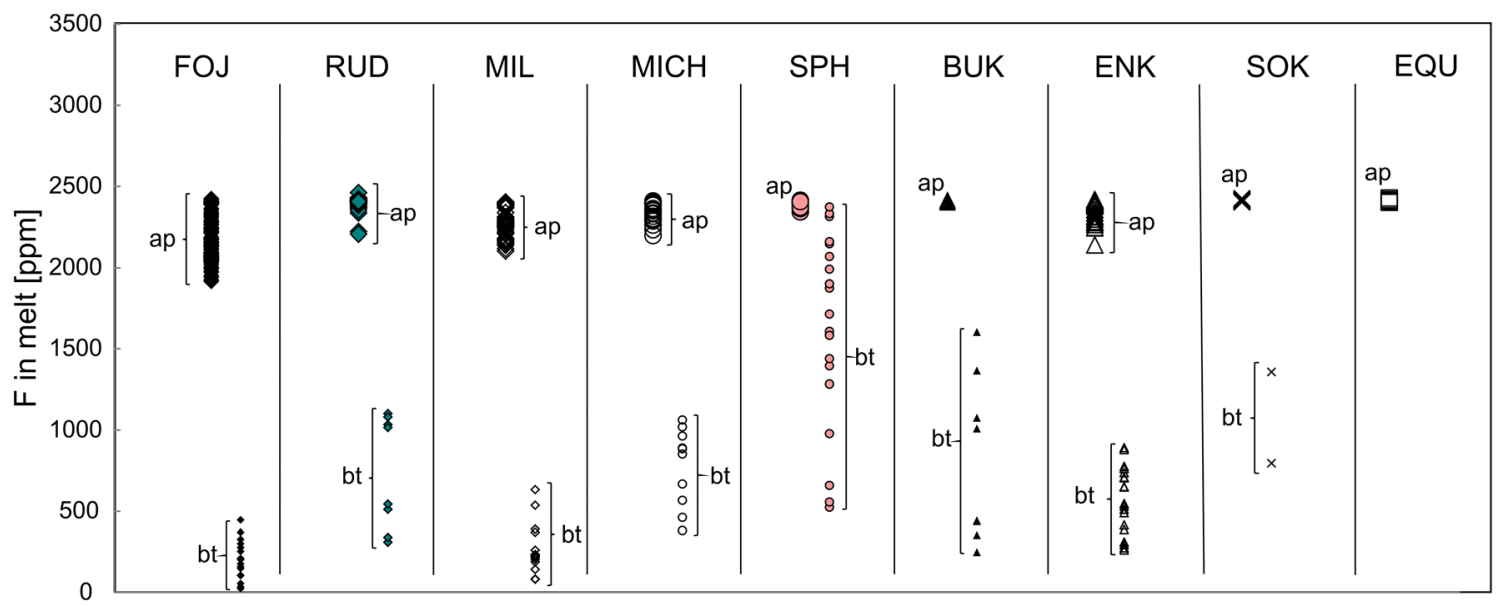

Fig. 4 Concentrations of F in the melt, calculated from apatite (ap) and biotite (bt) for all studied samples

concentrations of the melt are shown in Fig. 4 and show the widest range for FOJ granodiorites: 1915-2430 ppm. Slightly narrower ranges were provided for samples RUD, MIL and ENK (2200-2460 ppm, 2100-2400 ppm, 2140-2410 ppm, respectively). The remaining samples yielded average $\mathrm{F}$ contents of $\sim 2400 \mathrm{ppm}$. The concentrations of $\mathrm{F}$ in biotite show large variations, even within individual samples. The widest range of $\mathrm{F}$ contents is demonstrated by SPH biotites, which translates into $\mathrm{F}$ concentrations in the melt ranging from 520 to $2370 \mathrm{ppm}$.

Moderate abundances of $\mathrm{F}$ are exhibited by BUK, ENK, $\mathrm{MICH}$ and SOK biotites, giving narrower ranges of $\mathrm{F}$ content in the melt, with average values of 590, 570, 770 and $540 \mathrm{ppm}$, respectively. The lowest $\mathrm{F}$ content is demonstrated by FOJ and MIL biotites, leading to F-in-melt concentrations of 160 and $250 \mathrm{ppm}$, respectively.

\section{Major and trace element composition}

The complete dataset of chemical analyses of the studied titanites is given in the ESM (ESMA results in Table S4 and LA-ICP-MS results in Table S5). The most relevant textural and compositional features are summarized in Table 3.

\section{Lamprophyres}

There is not only textural, but also compositional difference between LAM1 and LAM2 titanites. LAM1 titanite is poor in $\mathrm{Ti}$ and $\mathrm{Fe}$, shows weak negative correlation between $\mathrm{Al}$ and Fe and higher $\mathrm{Al}_{2} \mathrm{O}_{3} / \mathrm{TiO}_{2}$ ratios compared to LAM2 titanite (Fig. 5a,c). It can be also characterized by high and positively correlated $\mathrm{Al}_{2} \mathrm{O}_{3}$ and $\mathrm{F}$ contents (up to 8.67 and $2.50 \mathrm{wt} \%$, respectively; Fig. 5e). LAM2 titanite is Ti- and Fe-rich, shows positive $\mathrm{Al}-\mathrm{Fe}$ correlation and lower $\mathrm{Al}_{2} \mathrm{O}_{3} / \mathrm{TiO}_{2}$ ratios (Fig. $5 \mathrm{a}, \mathrm{c}) . \mathrm{Al}_{2} \mathrm{O}_{3}$ and $\mathrm{F}$ contents are the lowest among titanites from all studied samples $(0.47$ and $0.28 \mathrm{wt} \%$, respectively, Fig. 5e). $\mathrm{Ti}^{4+} /\left(\mathrm{Al}+\mathrm{Fe}^{3+}\right)$ ratios show major differences between the two samples and are significantly higher for LAM2 titanite (11-38), compared to LAM1 titanite ( $<4$; Fig. 6). Grain interiors showing the highest crystallization temperatures exhibit the lowest $\mathrm{Al}_{2} \mathrm{O}_{3} / \mathrm{TiO}_{2}$ and the highest $\mathrm{Ti}^{4+}$ / $\left(\mathrm{Al}+\mathrm{Fe}^{3+}\right)$ ratios, whereas the margins display opposite values.

LA-ICP-MS analyses of trace elements were performed only for the LAM2 sample (Fig. 7a-g). The titanite demonstrates low total REE contents (compared to titanites from granodiorites and porphyritic granites) and strongly fractionated LREE-enriched chondrite-normalized REE patterns $\left(\mathrm{La}_{\mathrm{N}} / \mathrm{Yb}_{\mathrm{N}}=27-718\right.$, Fig. 8e). Very low Y contents (17$343 \mathrm{ppm})$ lead to the highest $(\mathrm{Ce}+\mathrm{Nd}) / \mathrm{Y}$ ratios among all samples (Fig. 7e,g). The titanite exhibits also the highest $\mathrm{Th} /$ $\mathrm{U}, \mathrm{La} / \mathrm{Sm}, \mathrm{La} / \mathrm{Ce}, \mathrm{Ce} / \mathrm{Nd}$ (Fig. 7 a,c) and the lowest Lu/Hf, Nb/ $\mathrm{Zr}$ and $\mathrm{Y} / \mathrm{Zr}$ ratios (Fig. 7e,g). Y/Ho ratio varies from 23.2 to 31.4 (Table 3). Sr contents are most elevated in LAM2 titanite and reach up to $1650 \mathrm{ppm}$. Compared to the remaining samples, the LAM2 titanite demonstrates also the lowest $U$ and HREE (heavy REE) contents. Trace element contents correlate well with $\mathrm{Zr}$-in-titanite crystallization temperatures. There is a significant decrease in concentrations of all trace elements (without exception) from the $\mathrm{Zr}$-rich grain interior to the $\mathrm{Zr}$ poor margin. Based on EPMA analyses and trace element concentration which are above the detection limit, the LAM1 titanite demonstrates significantly lower total REE and $\mathrm{Zr}$ contents, lower $(\mathrm{Ce}+\mathrm{Nd}) / \mathrm{Y}, \mathrm{Ce} / \mathrm{Nd}, \mathrm{Nb} / \mathrm{Zr}$ and higher $\mathrm{Y} / \mathrm{Zr}$ ratios (ESM; Table $\mathrm{S} 4$ ).

\section{Early stage - Hybrid granodiorites}

Titanite from both granodiorites, as well as all textural types (except BSE-dark rims), demonstrates similar chemistry in terms of major elements and $\mathrm{F}$ with only few differences. $\mathrm{TiO}_{2}$ content is generally lower compared to LAM2 titanite (but higher compared to LAM1 titanite), resulting in slightly higher $\mathrm{Al}_{2} \mathrm{O}_{3} / \mathrm{TiO}_{2}$ ratios (Fig. 5a). $\mathrm{Al}$ and $\mathrm{Fe}$ show strong 


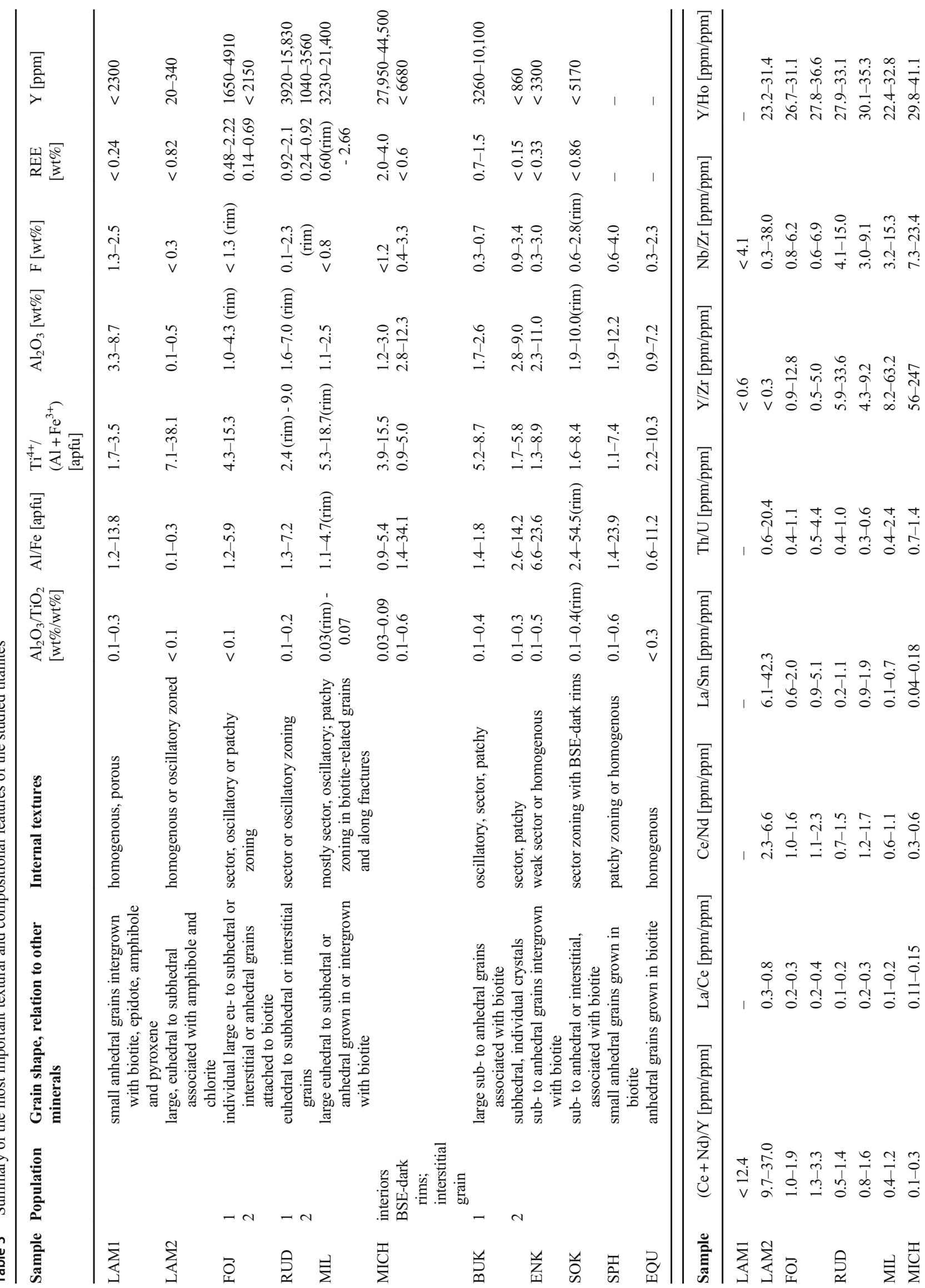




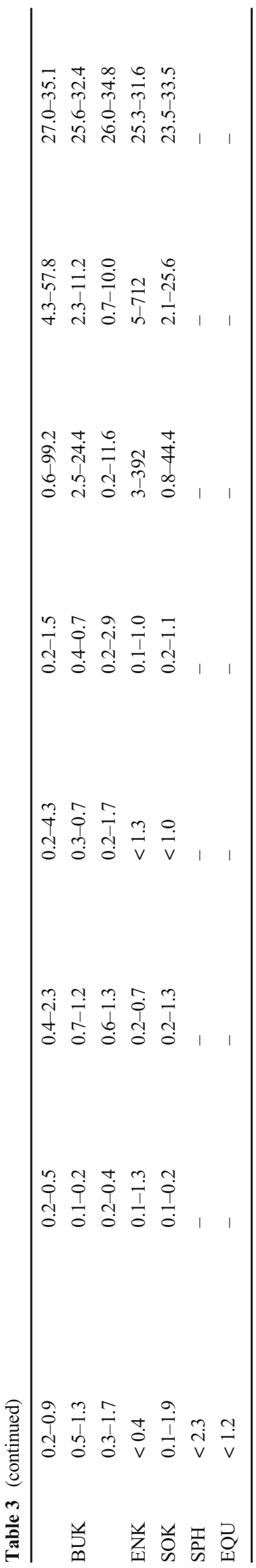

positive correlation with $\mathrm{Al} / \mathrm{Fe}$ ratios higher than $\mathrm{LAM} 2$ and lower than LAM1 titanites (Fig. 5c). $\mathrm{Al}_{2} \mathrm{O}_{3}$ and $\mathrm{F}$ contents are low (although higher than in LAM2 titanite) and uncorrelated (Fig. 5e). Compared to FOJ titanite, RUD titanite is slightly poorer in $\mathrm{TiO}_{2}$ and richer in $\mathrm{Fe}$ and $\mathrm{Al}$ (Fig. $\left.5 \mathrm{a}, \mathrm{c}\right) \mathrm{Ti}^{4+} /(\mathrm{Al}+$ $\mathrm{Fe}^{3+}$ ) ratios are significantly lower than in LAM2 titanite, but higher for FOJ titanite ( $>9)$, than for RUD titanite (2-9; Fig. 6). BSE-darker rims in some titanite grains show significantly larger $\mathrm{Al}_{2} \mathrm{O}_{3}$ and $\mathrm{F}$ contents (up to 7 and $2.3 \mathrm{wt} \%$, respectively, with positive $\mathrm{Al}_{2} \mathrm{O}_{3}$ versus $\mathrm{F}$ correlation, Fig. 5e), lower Ti concentrations (Fig. 5a), no correlation between $\mathrm{Fe}$ and $\mathrm{Al}$ (Fig. 5c) and significantly lower $\mathrm{Ti}^{4+} /\left(\mathrm{Al}+\mathrm{Fe}^{3+}\right)$ ratios (Fig. $6)$.

Titanites from granodiorites differ in terms of trace element composition not only between FOJ and RUD but also within individual samples. FOJ titanite can be divided into two principle groups. The first group (composed of mostly subhedral to interstitial grains) exhibits higher REE, $\mathrm{Y}, \mathrm{Nb}$ and $\mathrm{Sn}$ contents, lower $(\mathrm{Ce}+\mathrm{Nd}) / \mathrm{Y}, \mathrm{Th} / \mathrm{U}, \mathrm{La} / \mathrm{Ce}$ and $\mathrm{La} / \mathrm{Sm}$ and higher $\mathrm{Y} / \mathrm{Zr}$ and $\mathrm{Nb} / \mathrm{Zr}$ ratios (Fig. $7 \mathrm{~b}-\mathrm{h}$ ). Chondrite-normalized REE patterns are slightly less LREE-enriched compared to the second group, with La-Ce depletion, flat HREE profile and negative Eu anomaly (Fig. 8a). Y/Ho ratio ranges from 26.7 to 31.1 (Table 3). The second group (individual euhedral to subhedral grains, BSE-darker margins) shows significantly lower total REE contents, slightly lower $\mathrm{Nb}$, Sn concentrations, higher $(\mathrm{Ce}+\mathrm{Nd}) / \mathrm{Y}, \mathrm{Th} / \mathrm{U}, \mathrm{La} / \mathrm{Ce}, \mathrm{La} / \mathrm{Sm}$ and lower $\mathrm{Y} / \mathrm{Zr}$ and $\mathrm{Nb} / \mathrm{Zr}$ ratios (Fig. $7 \mathrm{~b}-\mathrm{h}$ ). Chondrite-normalized REE patterns are slightly LREE-enriched, with a flat HREE profile and positive Eu anomaly (Fig. 8b). Y/Ho is slightly higher, compared to the first group, reaching 36.6 (Table 3). Compositional gradient within single crystal is minor for both groups. Generally, FOJ titanite exhibits the highest $\mathrm{Th} / \mathrm{U}, \mathrm{Ce} /$ $\mathrm{Nd}$ and $(\mathrm{Ce}+\mathrm{Nd}) / \mathrm{Y}$ ratios among all samples (excluding LAM2; Fig. 7b-f).

RUD titanite generally demonstrates higher total REE and $\mathrm{Y}$ contents compared to FOJ titanite. Similar bimodality in trace element composition as in FOJ titanite is visible (excluding BSE-dark rims). The first group (euhedral to subhedral grains) exhibits higher $\mathrm{Y}, \mathrm{REE}, \mathrm{Nb}, \mathrm{Ta}$, Hf contents as well as lower $(\mathrm{Ce}+\mathrm{Nd}) / \mathrm{Y}, \mathrm{La} / \mathrm{Sm}, \mathrm{La} / \mathrm{Ce}, \mathrm{Ce} / \mathrm{Nd}$ and $\mathrm{Nb} / \mathrm{Ta}$ and higher $\mathrm{Y} / \mathrm{Zr}$ and $\mathrm{Nb} / \mathrm{Zr}$ ratios (Fig. $7 \mathrm{~b}-\mathrm{h}$ ). Chondritenormalized REE patterns are flat or slightly MREE (middle REE)-enriched, display highly pronounced negative Eu anomaly, strong La-depletion and flat HREE profile (Fig. 8c). Y/Ho ratio ranges from 27.9 to 33.1 (Table 3). The second group (subhedral grains or grain margins) demonstrates generally lower trace element contents but higher $(\mathrm{Ce}+\mathrm{Nd}) / \mathrm{Y}$, $\mathrm{La} / \mathrm{Sm}, \mathrm{La} / \mathrm{Ce}, \mathrm{Ce} / \mathrm{Nd}, \mathrm{Nb} / \mathrm{Ta}$ and lower $\mathrm{Y} / \mathrm{Zr}$ and $\mathrm{Nb} / \mathrm{Zr}$ ratios (Fig. 7b-h). Chondrite-normalized REE patterns are slightly to moderately LREE-enriched (with La-depletion) with slightly Tm-Yb-Lu-enriched HREE profile and positive to slightly negative Eu anomaly (Fig. 8d). Y/Ho ratios reach 35.3 
(Table 3). Compared to FOJ titanites, those from RUD show generally lower $(\mathrm{Ce}+\mathrm{Nd}) / \mathrm{Y}, \mathrm{Th} / \mathrm{U}, \mathrm{La} / \mathrm{Sm}, \mathrm{La} / \mathrm{Ce}, \mathrm{Ce} / \mathrm{Nd}$ and higher $\mathrm{Y} / \mathrm{Zr}, \mathrm{Nb} / \mathrm{Zr}$ ratios (Fig. $7 \mathrm{~b}-\mathrm{h}$ ). Compositional variations within single grains are the highest for the large subhedral grains (even excluding the BSE-dark rims) and are most pronounced for total REE and Y contents (up to 1.3 and $1 \mathrm{wt} \%$, respectively). Element ratios differ slightly from zone to zone.

Apart from BSE-dark rims, there is no apparent correlation between the trace element composition, calculated crystallization temperature and textural type. The zones with the highest $\mathrm{Zr}$ content are either REE-poor in relation to the neighboring domains or show the highest REE-enrichment (these occur mostly as BSE-bright sectors). BSE-dark rims with high F, $\mathrm{Al}$ and low $\mathrm{Zr}$ contents (included in the second population of both FOJ and RUD) display a significant general depletion in trace elements and higher $(\mathrm{Ce}+\mathrm{Nd}) / \mathrm{Y}$ ratios. The chondrite-normalized REE patterns of these margins either follow the shape of the remaining zones with only lower REE concentrations or become flat with a slight positive Eu anomaly and HREE enrichment.

\section{Internediate stage - Hybrid granites}

MIL titanite displays similar $\mathrm{TiO}_{2}, \mathrm{Al}_{2} \mathrm{O}_{3}$ and $\mathrm{F}$ contents as FOJ titanite (Fig. 5a,e). $\mathrm{TiO}_{2}$ and $\mathrm{Al}_{2} \mathrm{O}_{3}$ are negatively correlated, whereas $\mathrm{Al}_{2} \mathrm{O}_{3}$ and $\mathrm{F}$ show no correlation. Fe contents are slightly lower compared to titanite from granodiorites, resulting in higher $\mathrm{Al} / \mathrm{Fe}$ ratios (Fig. $5 \mathrm{c})$. $\mathrm{Ti}^{4+} /\left(\mathrm{Al}+\mathrm{Fe}^{3+}\right)$ ratios are between 7 and 20 (Fig. 6). BSE-dark rims and biotiterelated anhedral grains with lower calculated crystallization temperatures demonstrate usually higher $\mathrm{F}$ contents, lower $\mathrm{Al}_{2} \mathrm{O}_{3} / \mathrm{TiO}_{2}$ and higher $\mathrm{Ti}^{4+} /\left(\mathrm{Al}+\mathrm{Fe}^{3+}\right)$ ratios. $\mathrm{MICH}$ titanite (grain interiors) exhibit slightly lower $\mathrm{TiO}_{2}$ and significantly higher Fe contents (up to 0.11 apfu; Fig. 5a,c). $\mathrm{Al}_{2} \mathrm{O}_{3}$ and $\mathrm{F}$ concentrations are slightly higher than those of FOJ, RUD and MIL titanites, but show no correlation (Fig. 5e). $\mathrm{Ti}^{4+} /(\mathrm{Al}+$ $\mathrm{Fe}^{3+}$ ) ratios are between 2 and 15 (Fig. 6). BSE-dark rims on $\mathrm{MICH}$ titanite, as well as titanite growing in biotite, compared to the larger grain interiors, demonstrate higher and positively correlated $\mathrm{Al}_{2} \mathrm{O}_{3}$ and $\mathrm{F}$ contents (Fig. 5e), higher $\mathrm{Al}_{2} \mathrm{O}_{3} / \mathrm{TiO}_{2}$ and $\mathrm{Al} / \mathrm{Fe}$ ratios, and lower Fe contents (Fig. 5a,c). $\mathrm{Ti}^{4+} /(\mathrm{Al}+$ $\mathrm{Fe}^{3+}$ ) ratios are $<5$ (Fig. 6).

Trace element composition of the MIL titanite is relatively uniform. They exhibit high REE and Y contents (up to $2.65 \mathrm{wt} \%$ of total REE and $2.14 \mathrm{wt} \%$ of $\mathrm{Y}$ ) and moderate compositional gradient within single grains (mostly in MREE-HREE, Y and Nb contents). Chondrite-normalized REE patterns are flat or slightly MREE-enriched, with Ladepletion and strong negative Eu anomaly (Fig. 8f). (Ce+ $\mathrm{Nd}) / \mathrm{Y}, \mathrm{La} / \mathrm{Ce}$ and $\mathrm{Ce} / \mathrm{Nd}$ ratios are lower, whereas $\mathrm{Y} / \mathrm{Zr}$ and $\mathrm{Nb} / \mathrm{Zr}$ ratios are higher compared to FOJ and RUD titanites (Fig. 7d-h). Two of the analysed crystals show significantly higher $\mathrm{Th} / \mathrm{U}$ ratios which are consistently correlated with low $\mathrm{La} / \mathrm{Sm}$ and $\mathrm{Nb} / \mathrm{Ta}$ ratios (Fig. 7b), high total REE content and slightly lower Sn concentrations. These grains, however, do not distinguish themselves in terms of textures or major element/volatile chemistry. Y/Ho ratios vary between 22.4 and 32.8 (Table 3). Interior BSE-bright sectors with higher $\mathrm{Zr}$ content (and crystallization temperatures) display higher $\mathrm{Nb}$, Ta, Th and REE concentrations (sometimes only MREE). On the other hand, BSE-dark rims and biotiterelated grains, which crystallized from a cooler melt are significantly depleted in trace elements. However, in case of REE, the depletion is more significant for LREE and MREE which is expressed in lower LREE/HREE ratios. Y/Ho ratios of these rims are usually slightly higher compared to the grain interiors.

$\mathrm{MICH}$ titanite (interiors) demonstrates significantly higher Y content compared to MIL titanite (2.50-4.50 wt\%, the highest among titanites from all studied samples) and is HREE-enriched (up to 4500 ppm of Yb). Compositional variations within single grains are very high for some crystals, especially in case of Y. Chondrite-normalized REE patterns are highly fractionated and LREE-depleted, with a relatively flat HREE profile and pronounced negative Eu anomaly (Fig. 9a). Element ratios such as $\mathrm{Th} / \mathrm{U}, \mathrm{Y} / \mathrm{Zr}$ and $\mathrm{Nb} / \mathrm{Zr}$ are higher, whereas $\mathrm{La} / \mathrm{Sm}, \mathrm{La} / \mathrm{Ce}, \mathrm{Ce} / \mathrm{Nd}$ and $(\mathrm{Ce}+\mathrm{Nd}) / \mathrm{Y}$ are lower compared to titanites from LAM2, granodiorites and MIL granite (Fig. 7b-h). BSE-dark rims and one interstitial grain represent an entirely different trace element chemistry. Y and REE contents are significantly lower (up to $6600 \mathrm{ppm}$ of $\mathrm{Y}$ and 5800 ppm of total REE), similarly to HFSE (such as Nb, $\mathrm{Ta}, \mathrm{Th})$. Chondrite-normalized REE patterns are usually flat to moderately HREE-enriched with very weak negative or positive Eu anomaly (Fig. 9b). Y/Ho ratios of the grain interiors range from 27.0 to 35.1 (Table 3). Compared to grain interiors, BSE-dark rims (as well as anhedral grains related to biotite) display higher $(\mathrm{Ce}+\mathrm{Nd}) / \mathrm{Y}$ (although lower than in titanites from granodiorites and MIL granite), $\mathrm{La} / \mathrm{Ce}, \mathrm{Ce} / \mathrm{Nd}$ (comparable to FOJ, RUD and MIL titanites), $\mathrm{Nb} / \mathrm{Ta}$ and lower $\mathrm{Y} / \mathrm{Zr}, \mathrm{Nb} / \mathrm{Zr}$ and $\mathrm{Th} / \mathrm{U}$ ratios (Fig. $7 \mathrm{~b}-\mathrm{h}$ ). $\mathrm{Y} / \mathrm{Ho}$ ratios are considerably higher, compared to the grain interiors, reaching 41.1 (Table 3). Although trace element contents of one interstitial grain are similar to those of BSE-dark rims, the major element concentrations and ratios are consistent with the grain interiors of the remaining grains.

\section{Late stage - MME, composite dykes, evolved granites}

The first population of titanite from the BUK enclave (large subhedral, strongly zoned) shows a narrow range of chemical composition. It exhibits high $\mathrm{Ti}$ contents (comparable to RUD and MIL titanites), low $\mathrm{Al}_{2} \mathrm{O}_{3} / \mathrm{TiO}_{2}$ ratios, strong positive correlation between $\mathrm{Al}$ and $\mathrm{Fe}$ and low $\mathrm{Al} / \mathrm{Fe}$ ratios, comparable to those of RUD titanite (Fig. 5b,d). $\mathrm{Al}_{2} \mathrm{O}_{3}$ 

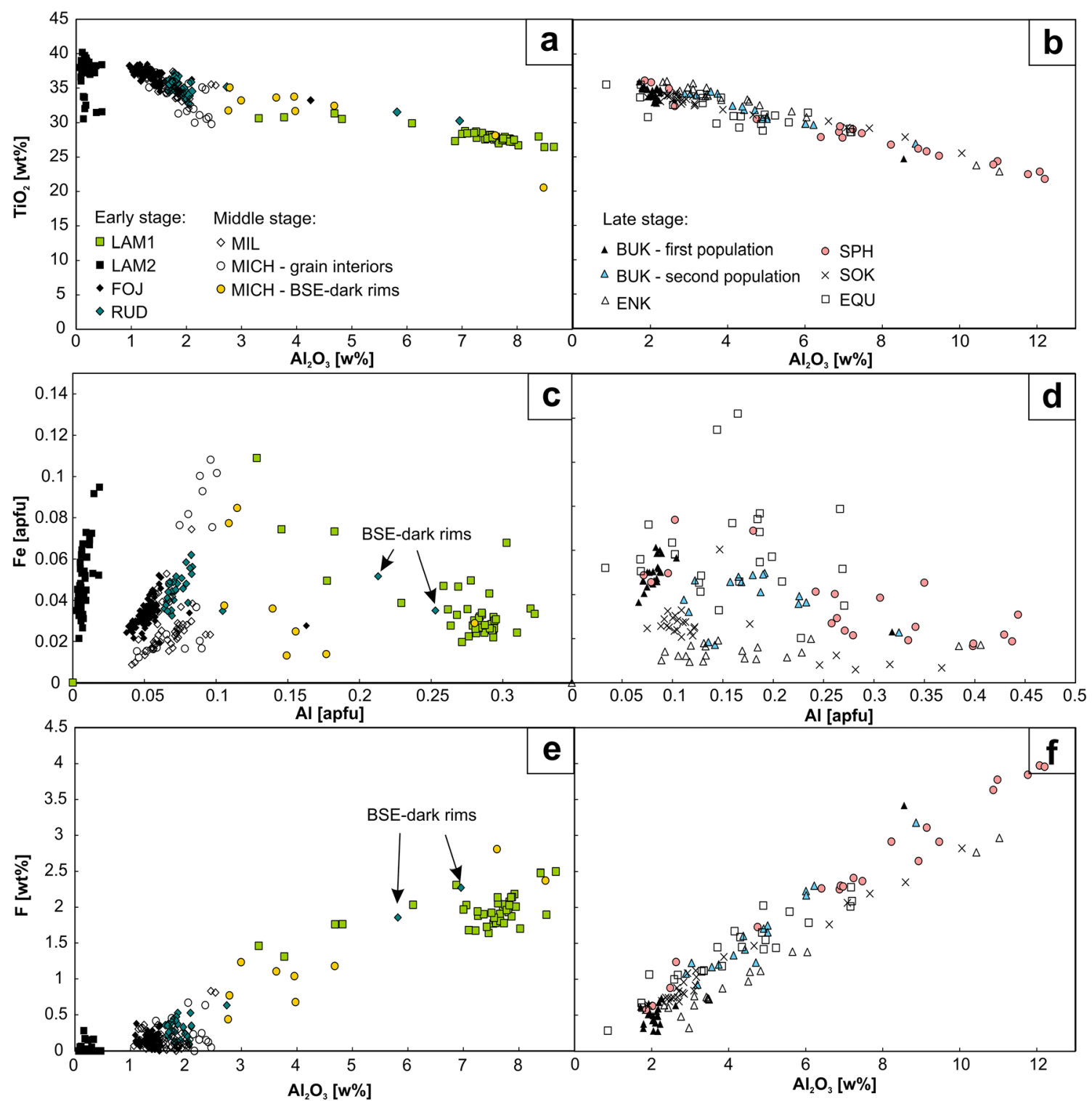

Fig. 5 Compositional variations for selected major elements and $\mathrm{F}$ in titanites from all studied samples. $\mathbf{a}, \mathbf{b}-\mathrm{Al}_{2} \mathrm{O}_{3}$ versus $\mathrm{TiO}$. $\mathbf{c}, \mathbf{d}-\mathrm{Al}$ versus $\mathrm{Fe}$. e,f $\mathrm{Al}_{2} \mathrm{O}_{3}$ versus $\mathrm{F}$

and $\mathrm{F}$ concentrations are low, however higher compared to titanites from early and intermediate stage hybrids (up to $\sim 2.5$ and $\sim 0.75 \mathrm{wt} \%$, respectively) and show no correlation (Fig. 5f). $\mathrm{Ti}^{4+} /\left(\mathrm{Al}+\mathrm{Fe}^{3+}\right)$ ratios are slightly lower, compared to titanites from early and intermediate stage hybrids and range from 5 to 9 (Fig. 6). The second population (small, individual grains), displays lower Ti contents, weak negative correlation between $\mathrm{Al}$ and $\mathrm{Fe}$ and higher $\mathrm{Al}_{2} \mathrm{O}_{3}$ / $\mathrm{TiO}_{2}$ and $\mathrm{Al} / \mathrm{Fe}$ ratios (Fig. 5b,d). $\mathrm{Al}_{2} \mathrm{O}_{3}$ and $\mathrm{F}$ contents can reach very high values ( $\sim 9$ and $\sim 3.5 \mathrm{wt} \%$, respectively) and are positively correlated (Fig. $5 \mathrm{f}) . \mathrm{Ti}^{4+} /\left(\mathrm{Al}+\mathrm{Fe}^{3+}\right)$ ratio is $<6$ (Fig. 6). Some grains from this population exhibit large compositional variations within single crystals, mainly in $\mathrm{Al}$ and $\mathrm{F}$ content. ENK titanite displays chemistry similar to that of the second type of BUK titanite, especially in terms of $\mathrm{TiO}_{2}, \mathrm{Al}_{2} \mathrm{O}_{3}, \mathrm{~F}$ contents and $\mathrm{Al}_{2} \mathrm{O}_{3} / \mathrm{TiO}_{2}$ ratio (Fig. 5b,f). On the other hand, $\mathrm{Fe}$ contents are significantly lower (Fig. $5 \mathrm{~d}) . \mathrm{Ti}^{4+} /\left(\mathrm{Al}+\mathrm{Fe}^{3+}\right)$ ratios cover a wide range of values, from 1 to 9 (Fig. 6).

Titanite from the composite dyke SOK demonstrates wide range of chemical composition, gradually changing from the crystal interiors to rims. Grain interiors exhibit generally higher Ti (compared to the rims, but lower than titanites from the early and intermediate stage hybrids) and no correlation between $\mathrm{Al}$ and $\mathrm{Fe}$ (Fig. 5b,d). $\mathrm{Al}_{2} \mathrm{O}_{3}$ and $\mathrm{F}$ contents are higher compared to titanites from early, intermediate stage hybrids (excluding the BSE-dark rims) and the first population of the BUK enclave and show positive correlation (2-3.20 wt $\%$ of $\mathrm{Al}_{2} \mathrm{O}_{3}$ and 0.5 to $1.2 \mathrm{wt} \%$ of $\mathrm{F}$; Fig. $5 \mathrm{f}) . \mathrm{Ti}^{4+} /\left(\mathrm{Al}+\mathrm{Fe}^{3+}\right)$ ratios show a 
Fig. 6 Variations in $\mathrm{Ti}^{4+} /(\mathrm{Al}+$ $\mathrm{Fe}^{3+}$ ) ratio (in apfu) among titanite from all studied samples. Labels "1st" and "2nd" denote the first and the second population of titanite from the BUK sample
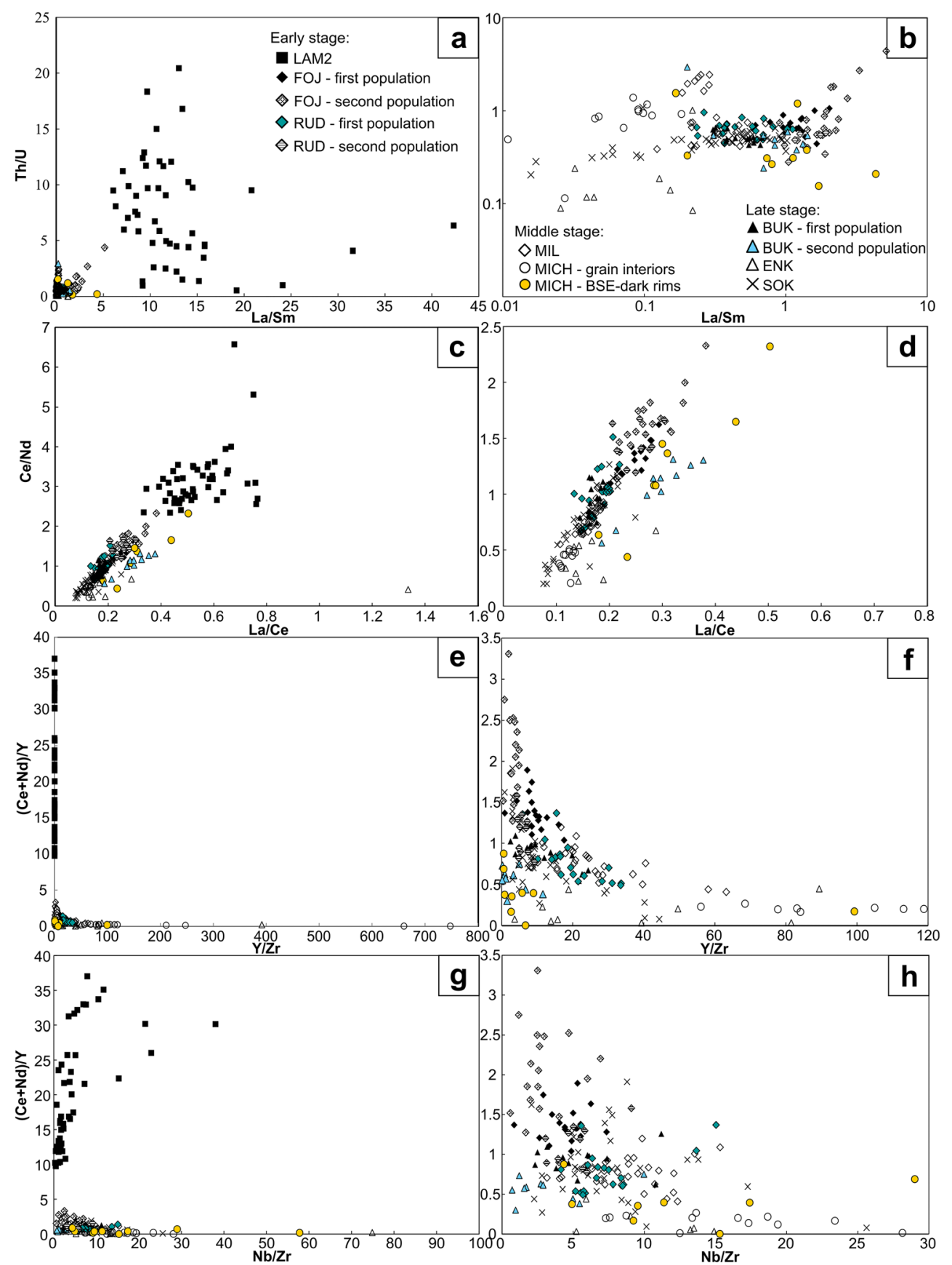

relatively narrow range of values (5-8; Fig. 6). BSE-dark rims show slightly lower $\mathrm{Ti}$ and $\mathrm{Fe}$ contents, higher $\mathrm{Al}_{2} \mathrm{O}_{3} / \mathrm{TiO}_{2}$ ratios and higher $\mathrm{Al}_{2} \mathrm{O}_{3}$ and $\mathrm{F}$ concentrations (up to $\sim 10$ and $2.75 \mathrm{wt} \%$, respectively; Fig. $5 \mathrm{~b}-\mathrm{f}$ ). $\mathrm{Ti}^{4+} /$ $\left(\mathrm{Al}+\mathrm{Fe}^{3+}\right)$ ratios are significantly lower than for the crystal interiors (Fig. 6).

Titanite from the evolved SPH granite displays a wide range of $\mathrm{Al}_{2} \mathrm{O}_{3}$ and $\mathrm{F}$ concentrations, containing the highest values among titanites from all studied samples (up to $\sim 12$ and $\sim 4 \mathrm{wt} \%$, respectively, Fig. $5 \mathrm{f}$ ). It is also characterized by generally lower $\mathrm{TiO}_{2}$ contents, higher $\mathrm{Al}_{2} \mathrm{O}_{3} / \mathrm{TiO}_{2}$ ratios and negative correlation between $\mathrm{Al}$ and Fe (Fig. 5b,d). Titanite from the most evolved EQU granite displays relatively low Ti contents, moderate $\mathrm{Al}_{2} \mathrm{O}_{3} / \mathrm{TiO}_{2}$ ratios, no correlation between $\mathrm{Al}$ and $\mathrm{Fe}$ and a wide range of $\mathrm{Al}_{2} \mathrm{O}_{3}$ and $\mathrm{F}$ compositions (0.9-7.1 wt \% and $0.25-2.25 \mathrm{wt} \%$, respectively), showing a strong positive correlation (Fig. $5 \mathrm{~b}-\mathrm{f}$ ). $\mathrm{Ti}^{4+} /\left(\mathrm{Al}+\mathrm{Fe}^{3+}\right)$ ratios exhibit a wide range of values, from 2 to 10 (Fig. 6).

The two populations of the BUK enclave also show differences in trace element composition. The first population (low $\mathrm{Al}_{2} \mathrm{O}_{3}$ and $\mathrm{F}$ ) exhibits higher $\mathrm{Y}, \mathrm{REE}, \mathrm{Sn}, \mathrm{Nb}, \mathrm{Ta}, \mathrm{Hf}$, Th and $\mathrm{U}$ concentrations compared to the second one. It demonstrates 
Fig. 7 Variations in selected trace element ratios among titanites from eight samples - LAM2, FOJ, RUD, MIL, MICH, BUK, ENK and $\mathrm{SOK}$. a,b $\mathrm{Nb} / \mathrm{Ta}$ versus $\mathrm{Th} / \mathrm{U}$. c,d La/Ce versus Ce/Nd. e,f $\mathrm{Y} / \mathrm{Zr}$ versus $(\mathrm{Ce}+\mathrm{Nd}) / \mathrm{Y} . \mathbf{g} / \mathbf{h ~ N b} /$ $\mathrm{Zr}$ versus $(\mathrm{Ce}+\mathrm{Nd}) / \mathrm{Y}$. The left diagrams (a, c, e, g) include LAM2 titanite with distinguishable ratios, while the right diagrams $(b, d, f, h)$ include only the remaining samples for clearer visualization. Data points with extreme $\mathrm{Nb} / \mathrm{Ta}, \mathrm{La} / \mathrm{Ce}, \mathrm{Y} / \mathrm{Zr}$ and $\mathrm{Nb} / \mathrm{Zr}$ ratios were removed from the plots

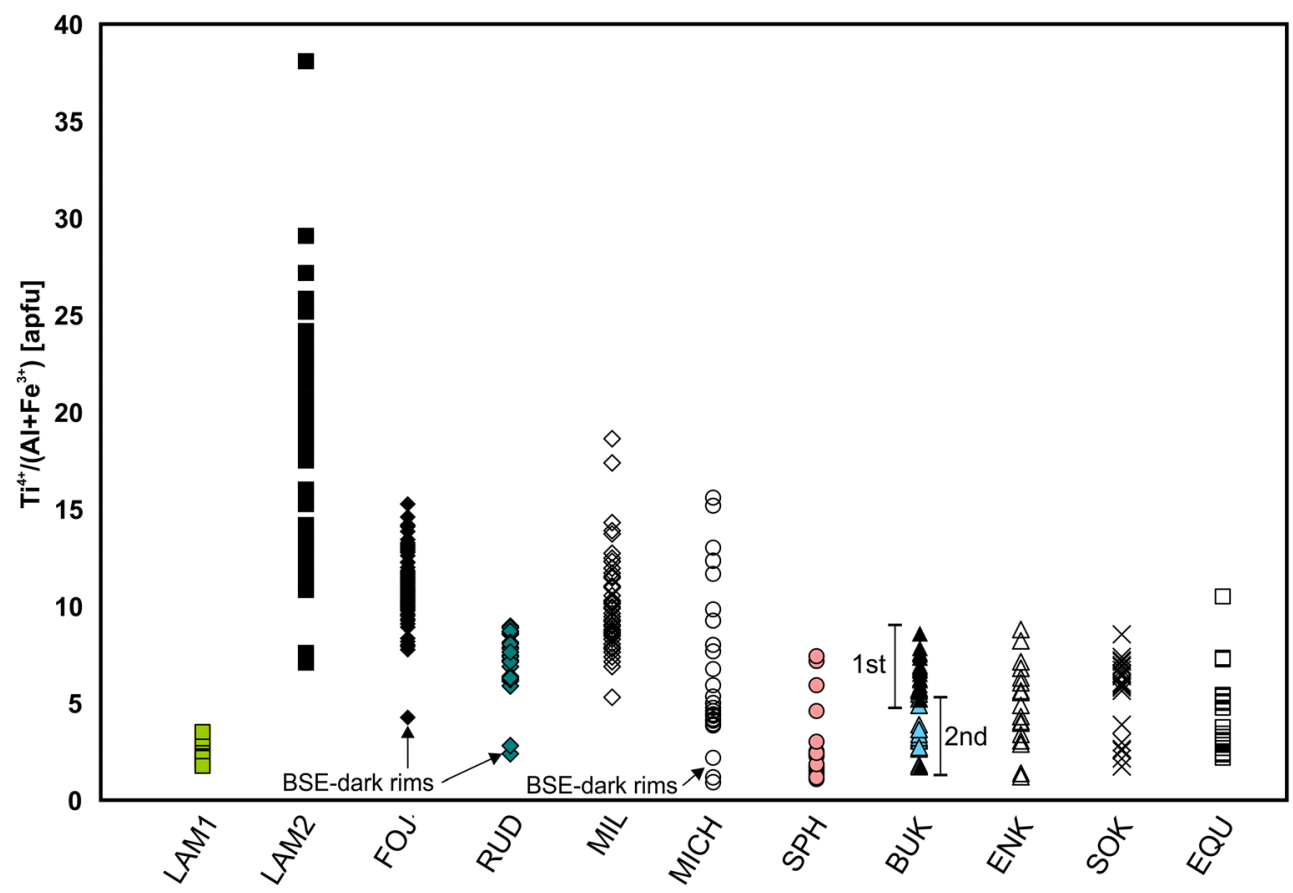

also higher $(\mathrm{Ce}+\mathrm{Nd}) / \mathrm{Y}, \mathrm{Y} / \mathrm{Zr}, \mathrm{Nb} / \mathrm{Zr}, \mathrm{Lu} / \mathrm{Hf}$ and lower $\mathrm{La} /$ $\mathrm{Ce}, \mathrm{Ce} / \mathrm{Nd}$ and $\mathrm{La} / \mathrm{Sm}$ ratios (similar to those of e.g. RUD and MIL titanites, i.e. early and intermediate stage; Fig. 7b-h). Both populations have similar $\mathrm{Th} / \mathrm{U}$ ratios, also comparable to those of titanites from the early and intermediate stage hybrids (Fig. 7b). Chondrite-normalized REE patterns are slightly MREE-enriched, La-depleted, with flat HREE profile and strong negative Eu anomaly (Fig. 9c). Y/Ho ratios of the first population range from 25.6 to 32.4 (Table 3 ). The second population is trace element-depleted, compared to the first one and demonstrates lower $(\mathrm{Ce}+\mathrm{Nd}) / \mathrm{Y}, \mathrm{Y} / \mathrm{Zr}, \mathrm{Nb} / \mathrm{Zr}$ and higher $\mathrm{La} / \mathrm{Ce}, \mathrm{Ce} / \mathrm{Nd}$ and $\mathrm{La} / \mathrm{Sm}$ ratios (Fig. $7 \mathrm{~b}-\mathrm{h}$ ). Chondrite-normalized REE patterns are relatively flat or slightly HREE-enriched, with weak negative or positive Eu anomaly (Fig. 9d). Y/Ho ratios are only slightly higher for two domains of the second population (reaching 34.8). Generally, the trace element composition of the second population resembles that of the BSE-dark rims of the MICH titanite (intermediate stage).

Titanite from the ENK enclave is generally poor in trace elements, similarly to the second population of the BUK titanite. Chondrite-normalized REE patterns are LREE-depleted (similar to intermediate stage titanite $\mathrm{MICH}$ ), with slightly negative or no Eu anomaly and flat Gd-Lu or slightly HREE-enriched profile (Fig. 9e). The titanite shows also particularly low $\mathrm{Th} / \mathrm{U}, \mathrm{La} / \mathrm{Sm}, \mathrm{La} / \mathrm{Ce}$, $\mathrm{Ce} / \mathrm{Nd}$ and $(\mathrm{Ce}+\mathrm{Nd}) / \mathrm{Y}$ ratio (Fig. $7 \mathrm{~b}-\mathrm{f}))$ and $\mathrm{Sn}$ contents. $\mathrm{Y} / \mathrm{Zr}$ and $\mathrm{Nb} / \mathrm{Zr}$ ratios are moderate, similar to those of titanite from the MICH granite (interiors; Fig. 7f,h). Y/Ho ratios vary between 25.3 and 31.6 (Table 3 ). Single grains showing slightly higher $\mathrm{Zr}$ contents and crystallization temperatures demonstrate the highest total REE concentration and the least LREE-depleted chondrite-normalized REE patterns.

Titanite from the SOK composite dyke shows a relatively narrow range of element concentrations (compared to early and intermediate stage hybrid titanites) but a wide range of element ratios. Total REE and Y contents are moderate and reach $\sim 0.9$ and $\sim 0.5 \mathrm{wt} \%$, respectively. Chondrite-normalized REE patterns form a continuous range from LREE-depleted with a flat HREE profile to slightly LREE-enriched, with Ladepletion and flat HREE profile (Fig. 9f). All patterns display negative $\mathrm{Eu}$ anomaly. $(\mathrm{Ce}+\mathrm{Nd}) / \mathrm{Y}, \mathrm{Th} / \mathrm{U}, \mathrm{Y} / \mathrm{Zr}$ and $\mathrm{Nb} / \mathrm{Zr}$ ratios are similar or slightly lower than those of titanites from early and intermediate stage hybrids (Fig. 7b-h), whereas La/ $\mathrm{Ce}, \mathrm{La} / \mathrm{Sm}, \mathrm{Ce} / \mathrm{Nd}$ of some $\mathrm{SOK}$ titanite grains (which are enriched in $\mathrm{Al}_{2} \mathrm{O}_{3}$ and $\mathrm{F}$ ) are one of the lowest among titanites from all studied samples. Y/Ho ratios range from 23.5 to 33.5 (Table 3) and are slightly higher for the rims. BSE-dark rims with lower $\mathrm{Zr}$ content show variable REE patterns, either following in shape those of the interior parts of the grains (only with lower concentrations) or MREE-enriched (these show also the lowest crystallization temperatures). The most distinguishable feature of the titanite from the composite dyke SOK is the elevated Sn content (up to $\sim 1.3 \mathrm{wt} \%$ ).

Unfortunately, there is no LA-ICP-MS trace element data on titanites from SPH and EQU granites, however, some general characteristics can be drawn from EPMA analyses with trace element concentrations above the detection limit (ESM; Table S4). SPH titanite is REE-poor ( REE $<5000$ ppm), with moderate $\mathrm{Y}$ concentrations $(<5000 \mathrm{ppm})$ and relatively low $(\mathrm{Ce}+\mathrm{Nd}) / \mathrm{Y}$ ratios $(<1)$. Titanite from the EQU granite 


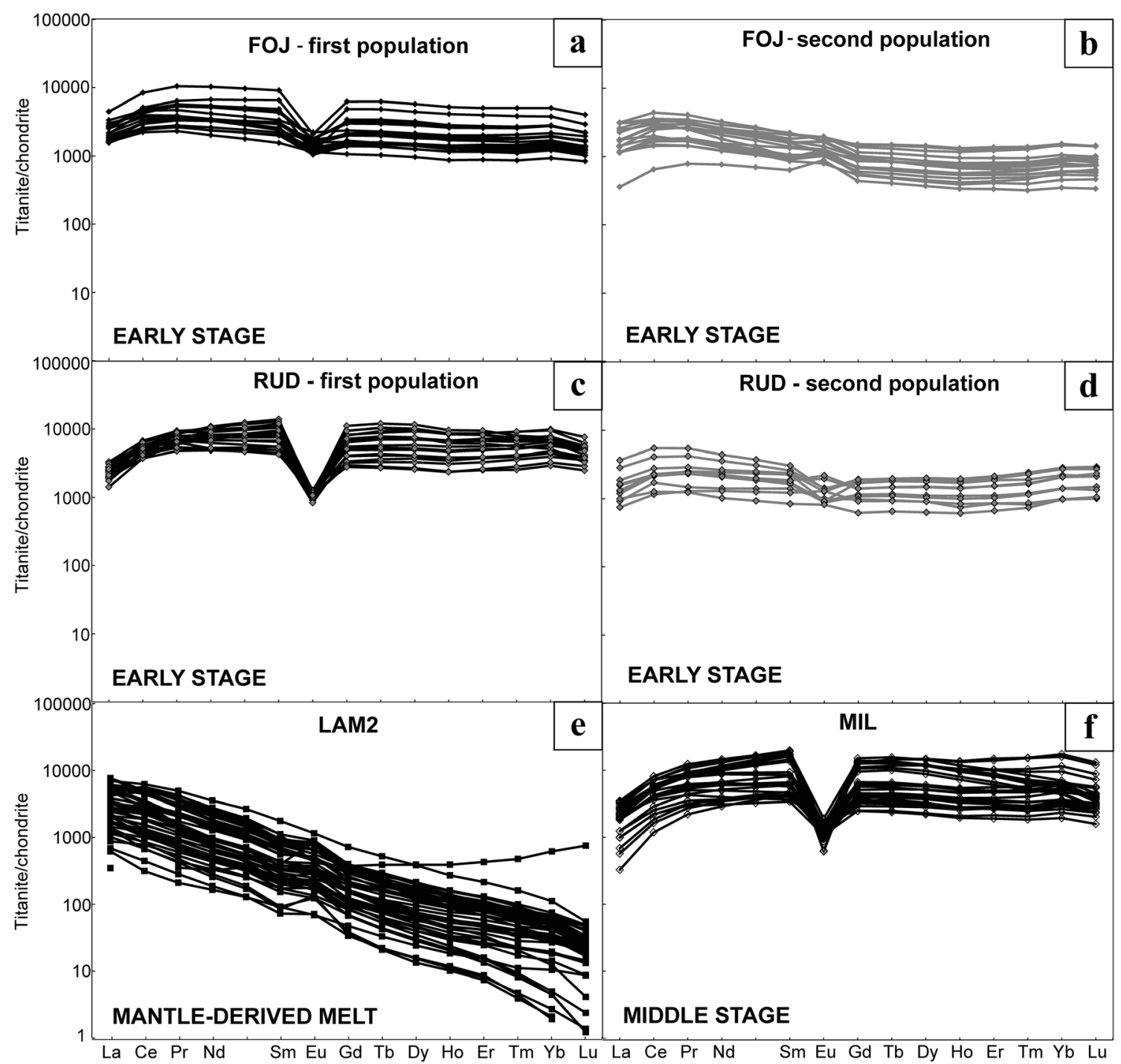

Fig. 8 Chondrite-normalized REE patterns for titanites from LAM2, FOJ, RUD and MIL samples. Chondrite-normalizing values are from Sun and McDonough (1989)

demonstrates similar trace element composition with few exceptions: higher Y content (up to $1 \mathrm{wt} \%$ ), lower total REE (up to $3300 \mathrm{ppm}$ ) and exceptionally high Sn content (up to $5 \mathrm{wt} \%)$.

\section{Discussion}

\section{General remarks}

Based on the wide range of textures and chemical composition in the studied titanites, two major types can be distinguished euhedral, subhedral or interstitial magmatic titanite and anhedral, biotite-related, most probably late- to postmagmatic titanite (which includes also BSE-dark crystal margins and patchy-zoned domains of some magmatic titanite grains). The magmatic titanite displays mostly sector, fir-tree or oscillatory zoning, and is generally REE-, Y-(except for LAM2), Zr-rich and Al-, F-poor. The late- to post-magmatic titanite exhibits either patchy zoning, homogenous or porous textures, and is trace element-poor (in rare cases there is a considerable Y-HREE-Nb-Sn enrichment), as well as Al-, Frich. The magmatic titanite constitutes the majority of LAM2, FOJ, RUD, MIL, MICH and SOK populations, is abundant in the BUK enclave, but very rare in the ENK enclave. The lateto post-magmatic titanite is rare in LAM2, FOJ, RUD, MIL, $\mathrm{MICH}$ and SOK samples, common in the BUK enclave and abundant in the ENK enclave. LAM1 contains only postmagmatic titanite. Each of the magmatic and post-magmatic stages are discussed separately, with emphasis on the magmatic evolution. The BSE-dark rims with lobate boundaries, as well as patchy zoned domains located along the margins or fissures are excluded from the discussion on magmatic titanite. 


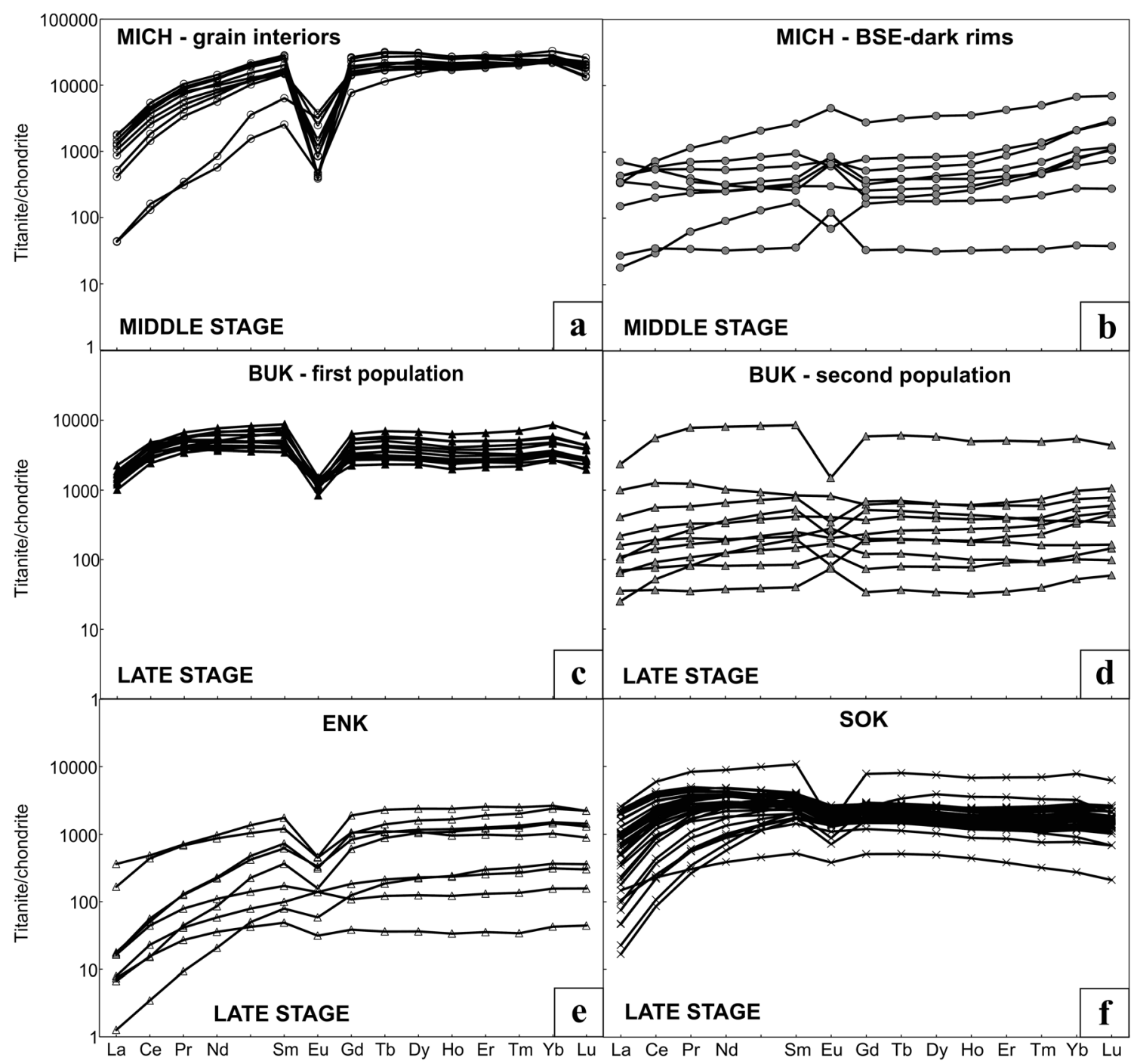

Fig. 9 Chondrite-normalized REE patterns for titanites from MICH, BUK, ENK and SOK samples. Chondrite-normalizing values are from Sun and McDonough (1989)

\section{Temperature relations in magmatic titanite}

The chemical compositions and textural patterns (sector, oscillatory, fir-tree zoning) of the first type of titanite (REE-rich, Al-F-poor) is typical for magmatic crystallization (regardless of the differences resulting from distinct melt compositions). Temperatures calculated from Zr-in-titanite thermometer (excluding ENK in which the second type dominates) are also within the magmatic stage range $\left(610-870{ }^{\circ} \mathrm{C}\right)$. The comparison with the temperatures calculated based on different models can shed some light on the more precise timing of titanite formation. In each studied sample, the highest temperatures were calculated for apatite, indicating its early growth. Higher values for lamprophyres and hybrid rocks reflect both the high temperature nature of mafic/mixed melts and P-rich character of these magmas (up to $1.32 \mathrm{wt} \%$ of $\mathrm{P}_{2} \mathrm{O}_{5}$; Słaby and Martin 2008; Awdankiewicz 2007). In more evolved varieties apatite crystallized in lower temperatures (e.g. in SPH or
EQU), reflecting higher $P$ solubility in peraluminous magmas (e.g. Broska et al. 2004). However, although apatite evidently crystallizes early in less peraluminous, P-rich melts, the calculated AST reflects the real temperatures only if apatites crystallizes in equilibrium with the melt (i.e. $\mathrm{P}_{2} \mathrm{O}_{5}$ decreases linearly with increasing silica content). In case of most P-rich hybrids (e.g. FOJ), most primitive porphyritic granites and MMEs the $\mathrm{P}_{2} \mathrm{O}_{5}$ versus $\mathrm{SiO}_{2}$ trend is least linear (Słaby and Martin 2008), indicating that the calculated temperature represents local conditions of apatite saturation. Nevertheless, as AST's only serve as a time frame for titanite crystallization, it can be assumed that the onset of apatite growth can be assigned to the early magmatic stage, clearly before titanite, which demonstrates temperatures lower by $\geq 150^{\circ} \mathrm{C}$.

A different relation is observed between zircon and titanite. In lamprophyres (LAM2) zircon saturation was achieved relatively late (Table 2), which is a function of major element composition, despite elevated $\mathrm{Zr}$ content. This may also 
explain higher $\mathrm{Zr}$ abundances in titanite itself (up to $1.66 \mathrm{wt} \%$ ), as titanite started to crystallize well before zircon. The lower temperatures calculated from external parts of titanite grains do not only reflect their late origin but also impoverishment of the melt in $\mathrm{Zr}$ due to zircon growth. In hybrid granodiorites and granites (early and intermediate stages of magmatic evolution) ZrTs are roughly within the temperature range shown by titanites, indicating that these minerals crystallized relatively simultaneously (except for the most $\mathrm{Zr}$-rich interiors in FOJ titanite) and suggesting equilibrated partition of $\mathrm{Zr}$ between the melt, zircon and titanite. In magmatic enclaves, as well as composite dykes, the onset of zircon crystallization is related to higher temperatures (> $800{ }^{\circ} \mathrm{C}$ ), than those represented by titanite, also pointing to equilibrated uptake of $\mathrm{Zr}$ by growing titanite.

In amphibole-bearing rocks titanite crystallized either after (lamprophyres, composite dykes) or simultaneously with (hybrid granites) amphibole. This, along with the AST, ZrT and textural context suggest that the onset of magmatic titanite growth took place roughly during the crystallization of rockforming minerals (after apatite and, in some cases, zircon) and continued after most of the rock-forming minerals have already crystallized.

Additionally, wide ranges of $\mathrm{Zr}$ content and temperatures, especially in early and intermediate stage granites, point to prolonged titanite crystallization, although there is no systematic correlation between the temperature and textural type (except for BUK, where the two populations show an apparent temperature difference). Moreover, $\mathrm{Zr}$ gradient may not only be a function of time (early hot versus later cooler melt), but also of melt composition (i.e. source). Magma mixing, which was the dominating process of melt differentiation during early to intermediate stages of the pluton evolution, assumes the presence of heterogenous melt domains of more mafic, mixed of felsic affinity. If titanite grew in a magma mixing regime, it may have preserved the footprint of both hotter, mafic-related and cooler, felsic-like magma domains. LAM2 titanite shows the highest $\mathrm{Zr}$ concentrations, up to $1.66 \mathrm{wt} \%$, which is understandable, as titanite is the principle $\mathrm{Zr}$-bearing phase in these rocks (Seifert and Kramer 2003). Domains with unusually elevated $\mathrm{Zr}$ content show high crystallization temperatures $\left(>850^{\circ} \mathrm{C}\right)$, which, despite being above the average temperature calculated for the entire titanite population, is well below the maximum temperature of lamprophyric melts (1000-1200 ${ }^{\circ} \mathrm{C}$, Esperanza and Holloway 1987). In some cases, unusually high concentrations of HFSE (e.g. Nb, Zr) may be the effect of disequilibrium uptake (previously documented by Watson and Liang 1995; McLeod et al. 2011; Bruand et al. 2014) resulting from high crystal growth rates and limited lattice diffusivity. It may be further facilitated by unlimited access to $\mathrm{Zr}$ in the melt, as zircon saturation temperature is significantly lower $\left(\sim 730^{\circ} \mathrm{C}\right)$. However, uncontrolled uptake of trace elements usually results in the formation of BSE-bright sector domains, which is not the case with the documented Zr-rich titanite zones. Moreover, chondrite-normalized REE patterns do not differ from those of the adjacent zones (except having slightly lower or higher concentrations of all REEs). Therefore, little textural evidence of disequilibrium uptake, as well as reasonable crystallization temperatures indicate that the $\mathrm{Zr}$-rich domains formed most probably earlier and from a hotter lamprophyric melt.

Single examples of exceptionally Zr-rich crystal zones (in relation to other domains from the same grain) are also present in FOJ, MIL, MICH, SOK and BUK titanites. Usually these zones occur as BSE-bright sectors in grain interiors. Temperature difference between these zones and the remaining crystal domains ranges from 30 to $140{ }^{\circ} \mathrm{C}$. Enrichment in $\mathrm{Zr}$ is usually of one order of magnitude higher than the remaining crystal domains and is accompanied by elevated $\mathrm{Nb}$, Ta and $\mathrm{Hf}$ contents (also of one order of magnitude higher than the adjacent zones). Chondrite-normalized REE patterns show no significant differences. Such characteristics are very similar to those reported by Bruand et al. (2014) that were interpreted as results of the selective disequilibrium uptake of trace element during sector zone growth. Although the temperatures calculated for the Zr-rich zones in the studied titanites do not exceed the estimates from other minerals/models and, thus, are plausible, the crystallization of two adjacent zones (with undisturbed contact between them) from melts differing by $140{ }^{\circ} \mathrm{C}$ in temperature, is difficult to explain. Moreover, there is no further evidence of crystallization from a compositionally distinct magma (between the BSE-bright sector and adjacent zones). Therefore, the elevated $\mathrm{Zr}$ content and resulting crystallization temperatures are most probably the result of sector growth typical for titanite and do not indicate the presence of hot mafic melt domains.

As the variations in $\mathrm{Zr}$ content and temperature are rather intergrain, than intra-grain, they might have resulted from different timing of titanite crystallization and/or growth from compositionally different melt 'pockets' (with different mafic to felsic melt ratios). The few examples of intra-grain variations may have preserved the record of titanite growth from a heterogenous magma. However, as the melt domains were most probably mixed to some degree (titanite crystallized after apatite and most rock-forming minerals), the temperature difference between them could not have been as high as that reflected by single-grain $\mathrm{Zr}$ variations. In the magma mixing regime trace elements are partitioned in non-linear way between the melt domains (e.g. Perugini et al. 2008), which may be the most plausible cause of elevated intra-grain $\mathrm{Zr}$ gradient. Moreover, significant compositional heterogeneity of magma in local scale would result also in major singlegrain trace element discrepancies, e.g. distinct REE patterns, which is mostly not the case (see further discussion). 


\section{Characteristics of mafic, mantle-related titanite}

Whereas compositional differences between magmatic and post-magmatic titanite are major, the distinction between magmatic titanite from different evolution stages may be less straightforward. In order to trace mantle-crust melt interactions in titanite composition, typical compositional features of relatively pure mafic titanite need to be established. The composition of primary magmatic LAM2 titanite can be considered as a basis for further comparison with the titanites from the remaining samples. The distinct geochemistry of the LAM2 lamprophyre dyke may have resulted either from source heterogeneity, source mixing, variable degree and depth of melting or overprinting by shallow-level differentiation processes (Awdankiewicz 2007). Nevertheless, despite slight compositional differences between individual lamprophyric dykes, the general characteristics of titanite major and trace element composition should demonstrate relative consistency. The most typical features of mafic titanite from Karkonosze granite include: the lowest $\mathrm{Al}_{2} \mathrm{O}_{3} / \mathrm{TiO}_{2}$ and $\mathrm{Al} / \mathrm{Fe}$ ratios, the lowest $\mathrm{F}$ and $\mathrm{Al}$ contents (Fig. 5e), the highest $\mathrm{Ti}^{4+} /$ $\mathrm{Al}+\mathrm{Fe}^{3+}$ ratio (Fig. 6), high $\mathrm{REE} / \mathrm{Y},(\mathrm{Ce}+\mathrm{Nd}$ )/Y, Th/U, La/ $\mathrm{Ce}$ and $\mathrm{Ce} / \mathrm{Nd}$ ratios (Fig. $7 \mathrm{a}-\mathrm{e}$ ), low $\mathrm{Y} / \mathrm{Zr}, \mathrm{Lu} / \mathrm{Hf}$, and $\mathrm{Nb} / \mathrm{Zr}$ ratios (Fig. 7e,g), LREE enriched chondrite-normalized REE patterns (Fig. 8e) and high $\mathrm{Sr}, \mathrm{Zr}$ and $\mathrm{Nb}$ contents. High $\mathrm{Ti}^{4+} /$ $\mathrm{Al}+\mathrm{Fe}^{3+}$ ratio $(>11)$ is indicative of mantle-related source regions (Piuzana et al. 2008) and values $>18$ are demonstrated exclusively by LAM2 titanite (among all studied samples). High $(\mathrm{Ce}+\mathrm{Nd}) / \mathrm{Y}, \mathrm{La} / \mathrm{Ce}$ and low $\mathrm{Nb} / \mathrm{Zr}, \mathrm{Y} / \mathrm{Zr}$ and $\mathrm{Lu} / \mathrm{Hf}$ ratios have been documented in titanite from mafic rocks and MMEs of the Mangling granitoid pluton ( $\mathrm{Hu}$ et al. 2017) and from intermediate rocks and MMEs of the Ross of Mull granite (McLeod et al. 2011), which both originated by mixing of mantle- and crust-derived sources. LREEenriched chondrite-normalized REE patterns are consistent with whole-rock REE patterns for lamprophyres (Słaby and Martin 2008), indicating equilibrium conditions of titanite crystallization. On the other hand, there are two features that are inconsistent with the whole-rock composition: positive $\mathrm{Eu}$ anomaly (Fig. 8e) and relatively low total REE content (compared to titanites from the granodiorites and granites). Positive Eu anomaly in accessory minerals crystallizing from granitoid rocks is usually attributed to fluid interaction (Horie et al. 2008). LAM2 titanite demonstrates primary magmatic textures (including oscillatory zoning) and bear no traces of fluid infiltration (Fig. 3a). In this case, the positive Eu anomaly can be explained by two facts: 1) absence of plagioclase in this particular dyke, and 2) oxidizing character of the melt, in which $\mathrm{Eu}^{3+}$ is more favoured by titanite structure than $\mathrm{Eu}^{2+}$ (Pan et al. 1993; Tiepolo et al. 2002). The former is most probably the principle cause of the positive Eu anomaly, which, most probably, is an individual feature of LAM2 titanite. Low REE content in titanite, in contrast to strong whole-rock REE enrichment in lamprophyres and higher REE concentrations in titanites from granodiorites and granites, can be explained by low titanite/melt partition coefficients for REEs in mafic melts. $K d_{R E E}^{t t h / m e l t}$ increase significantly with increasing melt polymerization and ASI (Alumina Saturation Index) (Prowatke and Klemme 2005, Prowatke and Klemme 2006), resulting in enhanced REE incorporation by titanite from granitoids. Due to large differences in partition coefficients for REEs, the total REE concentrations in titanite may not be directly indicative of the nature of the melt from which it originates.

\section{Early stages of magmatic evolution}

The general characteristics of mafic-related titanite can be traced in titanite from granodiorites FOJ and RUD. Total REE contents are significantly higher in this titanite, compared to those from lamprophyres (of magmatic origin), which may be caused by two facts: 1) REE-enrichment of the mafic melt and 2) higher melt-titanite partition coefficients for REEs, enhancing their incorporation into the titanite structure (Prowatke and Klemme 2006). Another cause of high REE concentrations may be related to higher $f \mathrm{O}_{2}$ of the magma. The early stages of magmatic evolution of the Karkonosze pluton are characterized by more oxidizing conditions (Adamuszek et al. 2009; Staby and Martin 2008) due to large proportions of mafic oxidized melt. Oxidizing character of the melt favours the following substitution: $\mathrm{REE}^{3+}+\mathrm{Fe}^{3+} \leftrightarrow \mathrm{Ca}^{2+}$ $+\mathrm{Ti}^{4+}$ (Piccoli et al. 2000), resulting in high REE contents. However, as titanite from more evolved granites, with minor contribution of the mafic magma, also demonstrates elevated REE concentrations, the $(\mathrm{Ce}+\mathrm{Nd}) / \mathrm{Y}$ ratio is more informative (as the granitic melt is enriched in Y compared to the mafic magma, Słaby and Martin 2008). The highest values are exhibited by titanite from the FOJ granodiorite (Fig. $7 \mathrm{f}, \mathrm{h}$ ), which agrees with the highest contribution of the mafic melt in this sample (Słaby and Martin 2008). Slightly lower ratios are displayed by RUD titanite, which may be partly explained by smaller contribution of the mafic melt. Interestingly, apatite also demonstrates a similar pattern of $\mathrm{REE} / \mathrm{Y}$ ratios among different samples (Lisowiec et al. 2015), suggesting that the participation of the mafic melt and its chemical signature can be detected in both minerals. Chondrite-normalized REE patterns of FOJ and RUD titanite do not resemble those of LAM2 titanite (Fig. 8a-e). FOJ titanite (especially the second, REE-depleted population), and some of RUD, which represent the second population, exhibit slightly visible LREE enrichment (with La-depletion), whereas the majority of RUD titanite shows flat (with La depletion, positive or negative $\mathrm{Eu}$ anomaly and $\mathrm{La}_{\mathrm{N}} / \mathrm{Yb}_{\mathrm{N}}<$ 1) REE patterns. Such shape cannot be explained merely by increasing contribution of the granitic melt or melt evolution, 
as whole-rock chondrite-normalized REE patterns are LREEenriched for all granodiorites of the Karkonosze pluton (Słaby and Martin 2008). The most probable cause is extensive crystallization of apatite prior to titanite formation. Apatite from most varieties of the Karkonosze granite is LREE-MREE-rich and its early crystallization most probably exhausted the LREE-MREE supply in the melt, resulting in flat REE pattern in titanite. Negative Eu anomaly demonstrated by first populations of both FOJ and RUD is demonstrated by the majority of primary magmatic titanite grains and can be related to plagioclase crystallization. The origin of the positive Eu anomaly is slightly more difficult to interpret. It is demonstrated by the entire second population of FOJ titanite and one grain of the second population of RUD titanite (Fig. 7c,e). These grains are slightly REE-depleted, compared to the first populations, but show higher $(\mathrm{Ce}+\mathrm{Nd}) / \mathrm{Y}, \mathrm{La} / \mathrm{Ce}$ and $\mathrm{Th} / \mathrm{U}$ ratios. Textures are euhedral to subhedral and are either homogenous or display sector to slightly patchy zoning. Some domains of titanite from this population exhibit also high $\mathrm{Zr}$ contents. Such characteristics may indicate that these crystals grew from a magma of more mafic affinity. Similar situation was observed in hybrid rocks from the Kłodzko- Złoty Stok granitoid pluton, which also formed from various proportions of mantle- and crust-derived magmas (Jokubauskas et al. 2015). In such context, positive Eu anomaly can be attributed to the more oxidizing character of the mafic melt, where $\mathrm{Eu}^{3+}$ enters the titanite structure by the following substitution: $\mathrm{REE}^{3+}+\mathrm{Fe}^{3+} \leftrightarrow \mathrm{Ca}^{2+}+\mathrm{Ti}^{4+}$ (Pan et al. 1993; Tiepolo et al. 2002). However, positive Eu anomaly in titanite (and in many accessory minerals) can be also interpreted in terms of fluidrelated interactions, as metasomatic oxidizing fluids interacting with the buffer host rock cause reduction of $\mathrm{Eu}^{3+}$ to $\mathrm{Eu}^{2+}$, which incorporates into the $\mathrm{Ca}$ site (Horie et al. 2008). In our case, such fluids could be of either internal postmagmatic origin or may have been supplied along with the mafic melt from the mantle. Titanite affected by the internal hydrothermal fluids would be significantly depleted in trace elements (as previously described post-magmatic titanite), whereas in case of mantle-derived fluids we would observe significant REE-enrichment (e.g. Słaby et al. 2011). In our case, the titanite is only slightly depleted in REEs. Therefore, it most probably formed from a magma with higher contribution of the mafic melt. However, in case of grains showing patchy zonation, the participation of late- to postmagmatic fluids cannot be excluded. The populations with high REE content, more flat REE patterns, negative Eu anomalies and lower $(\mathrm{Ce}+\mathrm{Nd}) / \mathrm{Y}, \mathrm{La} / \mathrm{Ce}$ and $\mathrm{Th} / \mathrm{U}$ ratios most probably represent titanite formed in magma with composition shifted more to the granitic end-member (however the contribution of the mafic melt is still significant).

Apart from rare earth elements, major and other trace element concentrations and ratios also show some affinity to the mafic mantle-related titanite. $\mathrm{Ti}^{4+} /\left(\mathrm{Al}+\mathrm{Fe}^{3+}\right)$ ratios are usually $>9$ (and overlap with some of the LAM2 titanite grains) for FOJ titanite, suggesting significant mantle contribution Piuzana et al. (2008) (Fig. 6). RUD titanite demonstrates slightly lower ratios (5-10), which can be partly explained by higher contribution of the granitic melt (evidenced also by whole-rock geochemistry) and decreased homogenization of the melt (presence of numerous small magmatic enclaves). $\mathrm{Al} / \mathrm{Fe}$ ratios are the lowest among titanites from all studied samples (except lamprophyres), which can be explained partly by high amounts of Fe-rich mafic melt. Fluorine contents are the lowest in FOJ titanite (except LAM2 titanite) and may be correlated with the lowest average $\mathrm{F}$ content of the melt $(2230 \mathrm{ppm})$ calculated based on apatite (Webster et al. 2009; Fig. 4). As mafic melts are F-poor, their higher contribution would result in lower $\mathrm{F}$ concentrations in hybrid melts. The low F content in melt calculated on the basis of biotite (Fig. 4) can be explained by late biotite crystallization (Naney 1983) and depletion in F due to apatite crystallization. Titanite from granodiorites demonstrates also elevated $\mathrm{Sr}$ contents, which is typical for accessory minerals formed in more mafic melts. Similarly to LAM2 titanite, $\mathrm{Y} / \mathrm{Zr}, \mathrm{Lu} / \mathrm{Hf}$ and $\mathrm{Nb} / \mathrm{Zr}$ ratios are very low, whereas $\mathrm{Th} / \mathrm{U}, \mathrm{La} / \mathrm{Ce}$ and $\mathrm{Ce} / \mathrm{Nd}$ are high for FOJ and RUD titanite. We interpret these similarities as an evidence of considerable mafic melt contribution.

The nature of magma mixing processes undergoing during the formation of titanite can also be deciphered looking at the compositional diversity of individual domains and grains. The inter-grain compositional variations between the first and second population (FOJ and RUD) are significantly higher compared to intra-grain chemical gradient (especially for the FOJ granodiorite). Among the growth textures, oscillatory and sector zoning dominate, whereas homogenous and patchy zoning is rare. The populations of more mafic affinity could have crystallized earlier, when the mafic melt was not yet mixed with granitic magma, whereas the titanite of more uniform composition grew in more or less homogenized melt pockets (which could still slightly differ in chemical composition) located between already crystallized mineral assemblages. Similar scenario for titanite crystallization was documented by Laurent et al. (2017). Additionally, in comparison to apatite and feldspar, titanite demonstrates decreased heterogeneity and almost exclusively mixed signature (more or less homogenized), whereas apatite and feldspar from granodiorites bear both mixed and pure mantle- or crust-related signature (Słaby et al. 2007a, 2007b; Lisowiec et al. 2015). It can be explained by early crystallization of these minerals, after which the melt could have undergone more advanced homogenization producing titanite of more uniform composition. Domain-todomain compositional variations are slightly increased in RUD titanite, suggesting the existence of compositionally distinct magma domains (even if slightly isolated) and enhanced mineral transfer. This is supported by a strong heterogeneous texture of the RUD granodiorite (Słaby and 
Martin 2008). It is important to note, that trace element variations between mineral populations as well as single growth zones are not mimicked by F. Similar situation is observed in apatites (Lisowiec et al. 2015). This may imply faster exchange of $\mathrm{F}$ between magma domains than for the remaining elements.

\section{Intermediate stages of magmatic evolution}

Titanite from the intermediate stage granites shows different chemical composition, suggesting changes in the magmatic environment during the intermediate stages of pluton formation. Some characteristics of MIL titanite are similar to those of titanite from granodiorites (low $\mathrm{Al}$ and $\mathrm{F}$ contents, relatively low F-inmelt content calculated from apatite - $2300 \mathrm{ppm}$, high $\mathrm{Ti}^{4+} /(\mathrm{Al}+$ $\left.\mathrm{Fe}^{3+}\right)$ ratios, similar $(\mathrm{Ce}+\mathrm{Nd}) / \mathrm{Y}$ ratio to RUD titanite, extremely high $\mathrm{Zr}$ and $\mathrm{Th} / \mathrm{U}$ for some grains or domains) and may still point to mafic melt involvement. However, the remaining compositional features, such as higher $\mathrm{Al} / \mathrm{Fe}, \mathrm{Al}_{2} \mathrm{O}_{3} / \mathrm{TiO}_{2}, \mathrm{Y} / \mathrm{Zr}, \mathrm{Nb} / \mathrm{Zr}$ and $\mathrm{Lu} / \mathrm{Hf}$ ratios, flat to LREE-depleted chondrite-normalized REE patterns and lower $\mathrm{La} / \mathrm{Ce}$ and $\mathrm{Ce} / \mathrm{Nd}$ ratios, indicate higher contribution of the granitic melt. Moreover, the mafic melt participating during the intermediate stages was more evolved compared to the primitive mafic magma from the early stages (Słaby and Martin 2008), which may also have caused different titanite composition. However, the exact determination of which features are caused by lower contents of the mafic melt and which by higher degree of the evolution of the mafic melt - is difficult, if not impossible. Chemical gradient in single grains is relatively high and similar as in RUD titanite. This, along with wide ranges of various element ratios, indicates significant magma heterogeneity (although with all compositions shifted more towards the granitic end-member) and enhanced mineral transfer between magma domains. The latter is also supported by complex zonation patterns for some titanite grains (e.g. Figure 5d). Uniform composition and mixed mantle-crust signature of the MIL titanite suggests crystallization from a hybrid magma, with the absence of pure mantle- or crust-derived domains. Similar case was observed in feldspar and apatite from this granite (Słaby et al. 2007a, 2007b; Lisowiec et al. 2015).

Titanite from the $\mathrm{MICH}$ granite (grain interiors) demonstrates further changes in chemical composition. It is most REE- and Y-enriched among all samples. Extremely high REE contents cannot be related to high mafic melt contribution as whole-rock data, felsic character of the rock and absence of any mixing textures exclude significant participation of mafic magma (Słaby and Martin 2008, sample POR10). The sample itself is enriched in REEs, which may the cause of high REE concentrations in both titanite and apatite (Lisowiec et al. 2015). Additionally, the MICH granite is also characterized by the highest ASI, thus, partition coefficients for REEs. High Y content, however, can be attributed to major involvement of the crust-derived granitic melt, supported also by higher $\mathrm{Al}$ content and $\mathrm{Al}_{2} \mathrm{O}_{3} / \mathrm{TiO}_{2}$ ratios, high $\mathrm{Sn}$, lower $(\mathrm{Ce}+\mathrm{Nd}) / \mathrm{Y}, \mathrm{La} / \mathrm{Ce}, \mathrm{Ce} / \mathrm{Nd}, \mathrm{La} / \mathrm{Sm}$ and higher $\mathrm{Y} / \mathrm{Zr}, \mathrm{Nb} / \mathrm{Zr}$ and $\mathrm{Lu} / \mathrm{Hf}$ ratios. Chondrite-normalized REE patterns are most LREE-depleted (Fig. 9a), which is caused by: 1) lower LREE/HREE ratios in granitic magma, 2) crystallization of other LREE-rich accessory minerals, such as apatite and monazite. Unfortunately, the absence of magmatic titanite in more evolved granites of documented crustal (or almost crustal) origin, exclude the comparison of MICH titanite to a crustrelated titanite. However, based on the distinct element ratios and REE patterns, we consider the MICH titanite as that of the least mafic melt contribution. F content of the melt calculated based on apatite is higher as for granodiorites and MIL granite, further supporting the dominating crustal character of the melt (Fig. 4). The crustal character of MICH titanite is in contrast with feldspar chemistry, which still points to moderate interaction between mafic and felsic melts (Slaby et al. 2007a, 2007b). However, feldspar started crystallizing well before titanite, where magma domains of more mafic affinity were still present. Titanite formed most likely from wellmixed melt of more granitic composition.

\section{Late stages of magmatic evolution}

Magmatic processes of the late stage of the pluton evolution can be mostly traced in titanite from the BUK enclave (earlier, REE-rich population) and SOK composite dyke, as those from the remaining rocks (ENK enclave, SPH and EQU granites) are related to late- and post-magmatic fluid interaction. BUK titanite, especially the first population with higher REEcontents and crystallization temperatures calculated from $\mathrm{Zr}$ concentrations, demonstrates similar $(\mathrm{Ce}+\mathrm{Nd}) / \mathrm{Y}, \mathrm{Y} / \mathrm{Zr}, \mathrm{La} /$ $\mathrm{Ce}$ and $\mathrm{Ce} / \mathrm{Nd}$ ratios as those from RUD and MIL titanites (Fig. 7c,e), which may point to some mafic affinity. However, this titanite also shows higher $\mathrm{F}$ and $\mathrm{Al}$ contents (compared to titanites from granodiorites and intermediate stage granites, Fig. 5e,f), relatively low $\mathrm{Ti}^{4+} /\left(\mathrm{Al}+\mathrm{Fe}^{3+}\right)$ ratios (similar to RUD titanite, Fig. 6) and relatively high Y contents. As in case of titanite from the MIL granite, such differences can be explained by higher contribution of the granitic melt and/ or higher degree of evolution of the mafic melt. As magmatic enclaves are the portions of mafic magma itself, more dominant cause of the compositional features of BUK titanite is the higher degree of evolution of the mafic magma (although high $\mathrm{Y}$ content is most probably related to the addition of granitic melt). However, the compositional characteristics, for which either crustal contribution or mafic melt evolution are responsible, are practically indiscernible from each other (which is already observed in titanite from the MIL granite). It appears, therefore, that titanite is not a suitable tool for distinguishing variable degree of melt evolution from different proportions of mafic versus felsic melts. Major and trace element composition of all magmatic crystals from the first population of the 
BUK enclave is relatively uniform and show minor inter- and intra-grain variations, suggesting crystallization from a relatively homogenous magma, which undergone extensive chemical exchange with the granitic host, acquiring more crust-related chemical signature. This is also supported by high F-in-melt content, calculated from apatite composition (Fig. 4). The uniform composition of titanite is in contrast with feldspar chemistry, which clearly points to crystallization from heterogeneous magma domains (alternating LREE-, Ba-rich and LREE-, Ba-poor growth zones; Słaby et al. 2008). However, feldspar crystallized before titanite and preserved the heterogeneous signature of yet not well-mixed environment, whereas titanite crystallized after considerable homogenization of magma.

Composition of SOK titanite demonstrates further changes in the magmatic environment. Some compositional features (e.g. high $\mathrm{REE}$ content, low $\mathrm{Lu} / \mathrm{Hf}, \mathrm{Y} / \mathrm{Zr}$ and $\mathrm{Nb} / \mathrm{Zr}$ ratios, Fig. $7 \mathrm{f}, \mathrm{h})$ are similar to titanite from the FOJ granodiorite, indicating the presence of the mafic-related component. On the other hand, decreasing $(\mathrm{Ce}+\mathrm{Nd}) / \mathrm{Y}$ (Fig. 7f), slightly higher $\mathrm{Al}$ and $\mathrm{F}$ (Fig. 5f) and relatively low $\mathrm{Ti}^{4+} /\left(\mathrm{Al}+\mathrm{Fe}^{3+}\right)$ ratios (Fig. 6) give evidence of increased interaction with the residual melt from the granitic host (as composite dykes intruded partially consolidated granite) and/or evolved character of the mafic melt (even more evolved compared to the mafic component from the BUK enclave). The distinction between the former and the latter is, as in case of BUK titanite, limited. The elevated $\mathrm{F}$ contents are in agreement with high F-in-melt content calculated from apatite composition (Fig. 4). It is important to note, that $\mathrm{Al}$ and $\mathrm{F}$ are positively correlated in SOK titanite, even though they are of magmatic origin. Some substitution mechanisms are triggered by elevated concentrations of relevant elements (Prowatke and Klemme 2006). Sufficiently high availability of $\mathrm{Al}$ and $\mathrm{F}$ most probably enabled the operation of the coupled substitution: $\mathrm{Al}^{3+}+$ $(\mathrm{OH}, \mathrm{F})^{-} \leftrightarrow \mathrm{Ti}^{4+}+\mathrm{O}^{2-}$ (e.g. Franz and Spear 1985). As the inter- and intra-grain chemical gradient is minor in SOK titanite, it can be stated that they crystallized from compositionally similar magma domains.

The evolution of titanite chemistry in more crust-related rocks from the late stage of pluton formation is impossible to trace, as the most evolved granitic rocks - SPH and EQU, do not contain magmatic titanite. The strong peraluminous and highly evolved composition of these rocks is most probably responsible for the absence of titanite. It is evident, that in case of the Karkonosze granitoid titanite can be only used in investigations of mafic and hybrid rocks, as the information about the crustal end-member is limited.

\section{Late- to post-magmatic titanite}

The late- to post-magmatic stage, reflected in various alteration of primary minerals and abundant mineralization, has been documented in many rock varieties from the Karkonosze pluton (Mochnacka and Banaś 2000; Pieczka and Gołębiowska 2002; Mikulski et al. 2004; Słaby 2005; Słaby et al. 2005; Kusiak et al. 2009; Mochnacka et al. 2015; Matyszczak 2018; Gros et al. 2020). Several attempts of dating the hydrothermal activity provided ages, among others, of $309 \pm 2$ (Re-Os in molybdenite, Mayer et al. 2012), $304 \pm 2$ (SHRIMP U-Pb in zircon, Kusiak et al. 2009) and $271 \pm 20 \mathrm{Ma}$ (CHIME of monazite and xenotime, Mikulski et al. 2004). Considering this wide range of obtained ages and their comparison with the average magmatic age of the pluton, the fluids must have circulated within the system over an extended period of time, leaving traces of their presence in many minerals.

Although the general chemical composition of the late- to post-magmatic titanite is relatively consistent (REE-poor, Al-, F-rich), the BSE-dark rims (and some entire sub- to anhedral, sector-zoned or homogenous grains) distinguish themselves from the anhedral, biotite-related, patchy-zoned and/or porous grains. The former formed most probably from a late, evolved (possibly residual) melt. Zr-in-titanite temperatures of the rims are still well within the magmatic range but point to a significantly cooler magma. Some ENK titanite crystals and the second population of BUK titanite also crystallized late. Fluorine content is elevated in these rims/crystals, compared to the magmatic titanite, but slightly lower than in titanites genetically related to biotite. Increasing F, as well as decreasing REE, coupled with slight HREE enrichment in chondritenormalized REE patterns, is consistent with the evolution of the granitic melt in Karkonosze (Słaby and Martin 2008). Higher Y/Ho ratios also point to the evolved nature of the melt, following the reasoning of Bau (1996). However, whether it is a late evolved magma or fluid-rich residual melt (Y/Ho ratios would be higher for both), is ambiguous, and may differ individually for each titanite/rim. A similar shape of REE patterns for some of the BSE-dark rims, compared to the grain interiors (only lower concentrations or, alternatively, slight HREE enrichment) would argue for a simple fractionation of the melt, but MREE enrichment, positive Eu anomaly and/or negative Ce anomaly in single cases may be evidence of fluid involvement. Moreover, variable shapes of the REE patterns of the domains/grains indicate local differences in the late magmatic/hydrothermal environment.

Whereas most of the late rims are BSE-dark, there are few examples of BSE-bright rims with lobate boundaries, indicating that they may have formed by ingression of fluids. The contact with the magmatic titanite forms a thin, very BSEbright zone, resembling slightly a reaction front. The rim is enriched in HREE, Y, Nb, F and Sn. Although the texture may be similar to that of the altered zircon reported by Kusiak et al. (2009), the composition is distinct (as the reaction front in the zircon is enriched in $\mathrm{Ca}, \mathrm{Ba}$ and $\mathrm{LREE}$ ), pointing to unrelated sources of the fluids. This type of alteration if more consistent 
with the NYF type of pegmatites described in the pluton (Pieczka and Gołębiowska 2002, Matyszczak 2018, Pieczka et al. 2015). Enrichment in Y, HREE, F and Th has also been documented in allanites from two composite dykes (Gros et al. 2020). However, this type of alteration is very rare in case of titanite. The few examples of BSE-dark rims with irregular boundaries that were measured by LA-ICP-MS, are depleted in all trace elements (except for HREE). Hydrothermal fluids are capable of mobilizing REE, among which LREE show higher mobility than HREE (Williams-Jones et al. 2012; Migdisov and Williams-Jones 2014; Migdisov et al. 2009, 2016). However, more stable REE complexes are formed with $\mathrm{Cl}$, compared to $\mathrm{F}$ or $\mathrm{OH}$ (Williams-Jones et al. 2012; Migdisov and Williams-Jones 2014; Migdisov et al. 2016). Presence of $\mathrm{Cl}$ cannot be directly inferred from the data obtained in this study but chlorine is often reported as an important component of the fluids responsible for the alteration of minerals in the Karkonosze rocks (Kusiak et al. 2009; Gros et al. 2020). On the other hand, increasing $F$ in potentially altered zones can indicate considerable amounts of $\mathrm{F}$ in the fluids. Given the low solubility of fluoride complexes with REE, the removed REE should have been immediately fixed in secondary minerals. These are, in turn, absent in the close vicinity of altered titanite. Therefore, the composition of the fluids, as well as the mechanisms of alteration in the rims or dark patches along the fractures present in some titanite grains (e.g. Fig. 3e), are difficult to determine on the basis of the available data and would require further investigation.

Although the temperatures calculated for the rims and anhedral grains are reasonable, the remobilization of $\mathrm{Zr}$ during fluid interaction has to be considered. In a mixed melt-fluid system, $\mathrm{Zr}$ is favourably partitioned into fluid (e.g. Louvel et al. 2014), indicating that a mineral crystallizing from a residual, fluid-bearing melt would be $\mathrm{Zr}$-poor. This, together with a lower temperature, may be the cause of the lower $\mathrm{Zr}$ content of the BSE-dark rims, especially those that follow the magmatic zoning (although the precise extent of either is difficult to determine). The lobate rims or patches affected by fluids may have experienced $\mathrm{Zr}$ removal, as $\mathrm{Zr}$ is mobile in the presence of both $\mathrm{F}$ - and Cl-bearing fluids and in temperatures $<500{ }^{\circ} \mathrm{C}$ (Rubin et al. 1993; Salvi et al. 2000; Gysi and Williams-Jones 2013), however, our data is insufficient to fully characterize the extent of the process.

The second type of post-magmatic titanite, intergrown with biotite and showing often patchy or porous texture, is extremely Al- and F-rich. Its shape and close association with biotite strongly supports its formation as a by-product of biotite chloritization (Eggleton and Banfield 1985). High F content is most probably a direct result of $\mathrm{F}$ release during biotite break-up (and possibly apatite dissolution during hydrothermal processes). Coupled enrichment in $\mathrm{Al}$ and $\mathrm{F}$ is caused by the onset of coupled substitution mechanism: $\mathrm{Al}^{3+}+(\mathrm{OH}, \mathrm{F})$ $\leftrightarrow \mathrm{Ti}^{4+}+\mathrm{O}^{2-}$ (e.g. Tropper et al. 2002). Increased $\mathrm{Al}$ and $\mathrm{F}$ contents are typical for hydrothermal titanite (e.g. Tulloch 1979; Morad et al. 2009). Elevated Al content is followed by significantly higher $\mathrm{Al}_{2} \mathrm{O}_{3} / \mathrm{TiO}_{2}$ ratios (up to 0.55 ), compared to magmatic titanite $(<0.12)$. There is also a shift in $\mathrm{Al} /$ Fe ratios from magmatic to hydrothermal titanite (from positive correlation and relatively low $\mathrm{Al} / \mathrm{Fe}$ ratios to negative or no correlation and variably high $\mathrm{Al} / \mathrm{Fe}$ ratios. This is in agreement with existing studies of hydrothermal titanite (Cao et al. 2015, Rasmussen et al. 2013, Morad et al. 2009). The shift from positive to negative $\mathrm{Al} / \mathrm{Fe}$ correlation is related to the change of substitution mechanism, from $(\mathrm{Al}, \mathrm{Fe})^{3+}+\mathrm{REE}^{3+}$ $\leftrightarrow \mathrm{Ti}^{4+}+\mathrm{Ca}^{2+}$ (e.g. Green and Pearson 1986) to the one involving $\mathrm{OH}$ and $\mathrm{F}$ (see above). Decreasing Fe content may be also related to low REE concentrations and, thus, minor participation of $\mathrm{REE}^{3+}+\mathrm{Fe}^{3+}$ substitution mechanism. The temperatures were calculated only for ENK anhedral, biotiterelated titanite and are not lower than $450{ }^{\circ} \mathrm{C}$. Although it clearly approaches the temperature range of hydrothermal stage (Cao et al. 2015 reported hydrothermal titanite formation in temperatures as high as $670^{\circ} \mathrm{C}$ ), the temperatures calculated for biotite chloritization in the Karkonosze granite are ca. $300{ }^{\circ} \mathrm{C}$ (isotopic fractionation of oxygen between quartz and chlorite, Wilamowski 2002). However, as the fluids most probably contained a considerable amount of $\mathrm{Zr}$ (see above), the calculated temperatures may be overestimated ( $\mathrm{Zr}$-intitanite geothermometer is dedicated for magmatic conditions). Furthermore, no enrichment in $\mathrm{Y}, \mathrm{Th}, \mathrm{Nb}$ (only slight in HREE) points to no relation with the fluids responsible for the Th-U mineralization or NYF signature of pegmatites.

In general, the traces of fluid activity in titanite are scarce. Their full characterization requires a more comprehensive investigation of the trace element footprint, especially as each type of rock cold have undergone a separate and compositionally distinct hydrothermal event.

\section{Conclusions}

In general, titanite chemical record shows major compositional variations between the studied samples. Several important conclusions can be drawn from our study. (i) Textural and chemical characteristics of titanite allowed the distinction between magmatic and late- to post-magmatic titanite. Magmatic titanite is present only in mafic, intermediate and less felsic rocks. It crystallized after apatite and relatively simultaneously with zircon and amphibole. Wide range of temperatures suggests prolonged growth, as well as crystallization from heterogeneous melt pockets. (ii) Typical compositional characteristics of the mafic titanite include: high $\mathrm{Ti}^{4+} /(\mathrm{Al}+$ $\left.\mathrm{Fe}^{3+}\right),(\mathrm{Ce}+\mathrm{Nd}) / \mathrm{Y}, \mathrm{Th} / \mathrm{U}$ ratios, low $\mathrm{Y} / \mathrm{Zr}, \mathrm{Nb} / \mathrm{Zr}, \mathrm{Lu} / \mathrm{Hf}$ ratios, low Al, F and high $\mathrm{Sr}, \mathrm{Zr}$ contents, strongly LREEenriched chondrite-normalized REE patterns and were recognized mostly in titanite from the early stages of magmatic 
evolution. In contrast, the most felsic titanite shows low $\mathrm{Ti}^{4+} /$ $\left(\mathrm{Al}+\mathrm{Fe}^{3+}\right),(\mathrm{Ce}+\mathrm{Nd}) / \mathrm{Y}$, high $\mathrm{Y} / \mathrm{Zr}, \mathrm{Lu} / \mathrm{Hf}$ ratios, higher $\mathrm{Al}$, $\mathrm{F}$, Sn and REE contents and HREE-enriched chondrite-normalized REE patterns. (iii) The early stage titanite recorded the presence of heterogeneous magma domains. The majority of titanite grains formed in more or less homogenized melt pockets of slightly different composition. Titanite from the intermediate and late stage hybrids demonstrates more uniform composition, suggesting crystallization from more homogenized magma of more felsic affinity. A gradual change from mafic to felsic signature preserved by titanite (in the sequence FOJ - RUD - MIL - MICH) indicates that its chemistry directly points to varying proportions of mafic versus felsic melt. However, it refers only to the early and intermediate stages, as in the late stage hybrids the titanite composition reflects two processes - higher contribution of the granitic magma and higher degree of evolution of the mafic melt. (iv) The late- to post-magmatic titanite is generally trace elementpoor and Al-, F-rich. It formed either from late, cooler and possibly residual melt, with some contribution of fluids or as a by-product of biotite chloritization. The character of the altered zones suggests removal of LREE and Y (and possibly Zr) and slight HREE enrichment.

Acknowledgements We thank two anonymous reviewers and journal editor Xisheng $\mathrm{Xu}$ for their constructive comments, which helped to improve significantly the quality of the manuscript. The study was founded by a grant for young scientists at the Institute of Geological Sciences, Polish Academy of Sciences ( 8 wewnętrzny konkurs na prowadzenie badan naukowych lub prac rozwojowych oraz zadań z nimi związanych, służących rozwojowi młodych naukowców oraz uczestników studiów doktoranckich). J.S. was supported by the Academy of Sciences of the Czech Republic institutional support to the Institute of Geology, Czech Academy of Sciences, through grant number RVO 67985831.

Open Access This article is licensed under a Creative Commons Attribution 4.0 International License, which permits use, sharing, adaptation, distribution and reproduction in any medium or format, as long as you give appropriate credit to the original author(s) and the source, provide a link to the Creative Commons licence, and indicate if changes were made. The images or other third party material in this article are included in the article's Creative Commons licence, unless indicated otherwise in a credit line to the material. If material is not included in the article's Creative Commons licence and your intended use is not permitted by statutory regulation or exceeds the permitted use, you will need to obtain permission directly from the copyright holder. To view a copy of this licence, visit http://creativecommons.org/licenses/by/4.0/.

\section{References}

Adamuszek M, John T, Dabrowski M, Podladchikov YY, Gertisser R (2009) Assimilation and diffusion during xenolith-magma interaction: a case study of the Variscan Karkonosze granite, bohemian massif. Mineral Petrol 97:203-222
Awdankiewicz M (2007) Late Palaeozoic lamprophyres and associated mafic subvolcanic rocks of the Sudetes (SW Poland): petrology, geochemistry and petrogenesis. Geol Sudetica 39:11-97

Awdankiewicz M, Awdankiewicz H, Kryza R (2005) Petrology of mafic and felsic dykes from the eastern part of the Karkonosze massif. Mineralogical Society of Poland - Special Papers 26:111-114

Barbarin B (1999) A review of the relationships between granitoid types, their origins and their geodynamic environments. Lithos 46:605626

Bau M (1996) Controls on the fractionation of isovalent trace elements in magmatic and aqueous systems: evidence from $\mathrm{Y} / \mathrm{ho}, \mathrm{Zr} / \mathrm{Hf}$, and lanthanide tetrad effect. Contrib Mineral Petrol 123:323-333

Broska I, Williams CT, Uher P, Konecny P, Leichmann J (2004) The geochemistry of phosphorus in different granite suites of the Western Carpathians, Slovakia: the role of apatite and P-bearing feldspar. Chem Geol 205:1-15

Bruand E, Storey C, Fowler M (2014) Accessory mineral chemistry of high $\mathrm{Ba}-\mathrm{Sr}$ granites from northern Scotland: constraints on petrogenesis and records of whole-rock signature. J Petrol 55:1619-1651

Cao MJ, Qin KZ, Li GM, Evans NJ, Jin LY (2015) In situ LA-(MC)-ICPMS trace element and $\mathrm{Nd}$ isotopic compositions and genesis of polygenetic titanite from the Baogutu reduced porphyry $\mathrm{Cu}$ deposit, Western Junggar, NW China. Ore Geol Rev 65:940-954

Eggleton RA, Banfield JF (1985) The alteration of granitic biotite to chlorite. Am Mineral 70:902-910

Esperanza S, Holloway JR (1987) On the origin of some micalamprophyres: experimental evidence from a mafic minette. Contrib Mineral Petrol 95:207-216

Green TH, Pearson NJ (1986) Rare-earth element partitioning between sphene and coexisting silicate liquid at high pressure and temperature. Chem Geol 55:105-119

Gros K, Słaby E, Jokubauskas P, Sláma J, Kozub-Budzyń G (2020) Allanite geochemical response to hydrothermal alteration by alkaline, low-temperature fluids. Minerals 10:92

Gysi AP, Williams-Jones AE (2013) Hydrothermal mobilization of pegmatite-hosted REE and $\mathrm{Zr}$ at Strange Lake, Canada: a reaction path model. Geochim Cosmochim Acta 122:324-352

Franz G, Spear FS (1985) Aluminous titanite (sphene) from the Eclogite Zone, south-central Tauern Window, Austria. Chem Geol 50(1-3): $33-46$

Frost BR, Chamberlain KR, Schumacher JC (2000) Sphene (titanite): phase relations and role as a geochronometer. Chem Geol 172: 131-148

Harrison TM, Watson EB (1984) The behaviour of apatite during crustal anatexis: equilibrium and kinetic considerations. Geochim Cosmochim Acta 48:1467-1477

Hayden LA, Watson EB, Wark DA (2008) A thermobarometer for sphene (titanite). Contrib Miner Petrol 155:529-540

Horie K, Hidaka H, Gauthier-Lafaye F (2008) Elemental distribution in apatite, titanite and zircon during hydrothermal alteration: durability of immobilization mineral phases for actinides. Phys Chem Earth 33(14-16):962-968

Hu H, Li JW, McFarlane CRM, Luo Y, McCarron T (2017) Textures, trace element compositions, and U-Pb ages of titanite from the mangling granitoid pluton, east Qinling Orogen: implications for magma mixing and destruction of the North China Craton. Lithos 284-285: $50-68$

Icenhower JP, London D (1997) Partitioning of fluorine and chlorine between biotite and granitic melt: experimental calibration at $200 \mathrm{MPa} H \mathrm{O}$ O. Contrib Mineral Petrol 127:17-29

Jiang P, Yang KF, Fan HF, Liu X, Cai YC, Yang YH (2016) Titanitescale insights into multi-stage magma mixing in early cretaceous of NW Jiaodong terrane, North China Craton. Lithos 258-269:197214 
Jokubauskas P, Baginski B, Macdonald R (2015) Evidence from titanite composition for the mixing of felsic and lamprophyric magmas in the Klodzko-Zloty Stok intrusion. Mineral Pol Spec Pap 44:54

Kryza R, Pin C, Oberc-Dziedzic T, Crowley QG, Larionov A (2014) Deciphering the geochronology of a large granitoid pluton (Karkonosze granite, SW Poland): an assessment of $\mathrm{U}-\mathrm{Pb}$ zircon SIMS and $\mathrm{Rb}-\mathrm{Sr}$ whole-rock dates relative to $\mathrm{U}-\mathrm{Pb}$ zircon CA-IDTIMS. Int Geol Rev 56:756-782

Kusiak MA, Dunkley DJ, Słaby E, Martin H, Budzyń B (2009) Sensitive high-resolution ion microprobe analysis of zircon reequilibrated by late magmatic fluids in a hybridized pluton. Geology 37:1063-1066

Kusiak MA, Williams IS, Dunkley DJ, Konečny P, Słaby E, Martin H (2014) Monazite to the rescue: U-Th-Pb dating of the intrusive history of the composite Karkonosze pluton, bohemian massif. Chem Geol 364:76-92

Laurent O, Zeh A, Gerdes A, Villaros A, Gros K, Słaby E (2017) How do granitoid magmas mix with each other? Insights from textures, trace element and $\mathrm{Sr}-\mathrm{Nd}$ isotopic composition of apatite and titanite from the Matok pluton (South Africa). Contrib Mineral Petrolo 172(9):80

Lisowiec K, Słaby E, Förster HJ (2015) Polytopic vector analysis (PVA) modelling of whole-rock and apatite chemistry from the Karkonosze composite pluton (Poland, Czech Republic). Lithos 230:105-120

Louvel M, Sanchez-Valle C, Malfait WJ, Cardon H, Testemale D, Hazemann J-L (2014) Constraints on the mobilization of $\mathrm{Zr}$ in magmatic-hydrothermal processes in subduction zones from in situ fluid-melt partitioning experiments. Am Mineral 99(8-9):16161625

Matyszczak W (2018) Liandratite from Karkonosze pegmatites, Sudetes, southwestern Poland. Mineral Petrol 112:357-370

Mayer W, Creaser RA, Mochnacka K, Oberc-Dziedzic T, Pieczka A (2012) Isotopic Re-Os age of molybdenite from the Szklarska Poręba Huta quarry (Karkonosze, SW Poland). Geol Quarterly 56: $505-512$

Mazur S, Aleksandrowski P (2001) The Tepla(?)/Saxothuringian suture in the Karkonosz-Izera massif, western Sudetes, central European Variscides. Int J Earth Sci 90:341-360

McLeod GW, Dempster TJ, Faithfull JW (2011) Deciphering magmamixing processes using zoned titanite from the Ross of Mull granite, Scotland. J Petrol 52:55-82

Migdisov AA, Williams-Jones AE (2014) Hydrothermal transport and deposition of the rare earth elements by fluorine-bearing aqueous liquids. Mineral Deposita 49(8):987-997

Migdisov AA, Williams-Jones AE, Wagner T (2009) An experimental study of the solubility and speciation of the rare earth elements (III) in fluoride- and chloride-bearing aqueous solutions at temperatures up to 300C. Geochim Cosmochim Acta 73:7087-7109

Migdisov A, Williams-Jones AE, Brugger J, Caporuscio FA (2016) Hydrothermal transport, deposition, and fractionation of the REE: experimental data and thermodynamic calculations. Chem Geol 439:13-42

Mikulski SZ, Bagiński B, Dzierżanowski P (2004) The CHIME age calculations on monazite and xenotime in aplogranite from the Szklarska Poręba Huta. Mineral Pol Spec Pap 24:287-290

Mochnacka K, Banaś M (2000) Occurrence and genetic relationships of uranium and thorium mineralization in the Karkonosze Izera block (the Sudety Mts, SW Poland). Ann Soc Geol Pol 70:137-150

Mochnacka K, Oberc-Dziedzic T, Mayer W, Pieczka A (2015) Ore mineralization related to geological evolution of the Karkonosze- Izera massif (the Sudetes, Poland) - towards a model. Ore Geol Rev 64: 215-238

Morad S, El-Ghali MAK, Caja MA, Al-Ramadan K, Mansurbeg H (2009) Hydrothermal alteration of magmatic titanite: evidence from Proterozoic granitic rocks, southeastern Sweden. Can Mineral 47: 801-811

Naney MT (1983) Phase equilibria of rock-forming ferromagnesian silicates in granitic systems. Am J Sci 283:993-1033
Pan Y, Fleet ME, Macrae ND (1993) Late alteration in titanite (CaTiSiO5): redistribution and remobilization of rare earth elements and implications for $\mathrm{u} / \mathrm{pb}$ and $\mathrm{th} / \mathrm{pb}$ geochronology and nuclear waste disposal. Geochim Cosmochim Acta 57(2):355-367

Pasero M, Kampf AR, Ferraris C, Pekov IV, Rakovan J, White TJ (2010) Nomenclature of the apatite supergroup minerals. Eur J Mineral 22: 163-179

Patočka F, Fajst M, Kachlik V (2000) Mafic, felsic to mafic-ultramafic early Palaeozoic magmatism of the west Sudetes (NE bohemian massif): the south Krkonosze complex. Z Geol Wissenschaf 28: $177-210$

Pearce NJG, Perkins WT, Westgate JA, Gorton MP, Jackson SE, Neal CR, Chenery SP (1997) A compilation of new and published major and trace element data for NIS T SRM 610 and NIST SRM 612 glass reference material. Geostand Newslett 21:115-144

Perugini D, De Campos CR, Dingwell DB, Petrelli M, Poli G (2008) Trace element mobility during magma mixing: preliminary experimental results. Chem Geol 256:146-157

Piccoli P, Candela P, Rivers M (2000) Interpreting magmatic processes from accessory phases: titanite - a small-scale recorder of largescale processes. T Roy Soc Edin:Earth 91:257-267

Pieczka A, Gołębiowska B (2002) Pegmatites of the Szklarska Poręba Huta granite quarry: preliminary data on REE mineralization. Mineral Pol Spec Pap 20:175-177

Piuzana D, Castañeda C, Noce CM, Pedrosa Soarez AC, Silva LC (2008) Titanite crystal chemistry and $\mathrm{U}-\mathrm{Pb}$ isotopic data: a petrogenetic indicator for Precambrian granitoid plutons oft he eastern Brazilian shield. Geonomos 16(1):29-36

Prowatke S, Klemme S (2005) Effect of melt composition on the partitioning of trace elements between titanite and silicate melt. Geochim Cosmochim Acta 69:695-709

Prowatke S, Klemme S (2006) Rare earth element partitioning between titanite and silicate melts: Henry's law revisited. Geochim Cosmochim Acta 70:4997-5012

Raczek I, Stoll B, Hofmann AW, Jochum KP (2001) High-precision trace element data for the USGS reference materials BCR-1, BCR-2, BHVO-1, BHVO-2, AGV-1, AGV-2, DTS-1, DTS-2, GSP-1 and GSP-2 by ID-TIMS and MIC-SSMS. Geostand Newslett 25:77-86

Rasmussen B, Fletcher IR, Muhling JR (2013) Dating deposition and low-grade metamorphism by in situ U-Pb geochronology of titanite in the Paleoproterozoic Timeball Hill formation, southern Africa. Chem Geol 351:29-39

Ridolfi F, Renzulli A, Puerini M (2010) Stability and chemical equilibrium of amphibole in calc-alkaline magmas : an overview, new thermobarometric formulations and application to subductionrelated volcanoes. Contrib Mineral Petrol 160:45-66

Rubin JN, Henry CD, Price JG (1993) The mobility of zirconium and other and other "immobile" elements during hydrothermal alteration. Chem Geol 110:29-47

Salvi S, Fontan F, Monchoux P, Williams-Jones AE, Moine B (2000) Hydrothermal mobilization of high field strength elements in alkaline igneous systems: evidence from the Tamazeght complex (Morocco). Econ Geol 95(3):559-576

Seifert W, Kramer W (2003) Accessory titanite: an important carrier of zirconium in lamprophyres. Lithos 71(1):81-98

Słaby E (2005) CHARAC- non-CHARAC behaviour of Y/Ho and $\mathrm{Zr} / \mathrm{Hf}$ in Karkonosze hybridic and granitic melts. Mineral Pol Spec Pap 25: 200-203

Słaby E, Martin H (2005) Mechanisms of differentiation of the Karkonosze granite. Mineralogical Society of Poland - Special Papers 26:264-267

Staby E, Martin H (2008) Mafic and felsic magma interaction in granites: the Hercynian Karkonosze pluton (Sudetes, bohemian massif). J Petrol 49:353-391

Słaby E, Götze J (2004) Feldspar crystallization under magma mixing conditions shown by cathodoluminescence and geochemical 
modelling: case study from the Karkonosze pluton (SW Poland). Mineral Mag 68:541-557

Słaby E, Galbarczyk-Gasiorowska L, Baszkiewicz A (2002) Mantled alkali-feldspar megacrysts from the marginal part of the Karkonosze granitoid massif (SW Poland). Acta Geol Pol 52:501519

Słaby E, Michalik M, Mierzejewski M (2005) Zr-Y-HREE enriched granitic vein rock from Karkonosze (SW Poland) - record of early fractionation of crustal melt? Mineral Pol Spec Pap 25:204-207

Słaby E, Galbarczyk-Gąsiorowska L, Seltmann R, Müller A (2007a) Alkali feldspar megacryst growth: geochemical modelling. Mineral Petrol 68:1-29

Słaby E, Seltmann R, Kober B, Müller A, Galbarczyk-Gąsiorowska L, Jeffries T (2007b) LREE distribution patterns in zoned alkali feldspar megacrysts-implication for parental melt composition. Mineral Mag 71:193-217

Słaby E, Götze J, Wörner G, Simon K, Wrzalik R, Śmigielski M (2008) K-feldspar phenocrysts in microgranular magmatic enclaves: a cathodoluminescence and geochemical study of crystal growth as a marker of magma mingling dynamics. Lithos 105:85-97

Słaby E, Śmigielski M, Domonik A, Simon K, Kronz A (2011) Chaotic three-dimensional distribution of $\mathrm{Ba}, \mathrm{Rb}$ and $\mathrm{Sr}$ in feldspar megacrysts grown in an open magmatic system. Contrib Mineral Petrol 162:909-927

Tiepolo M, Oberti R, Vannucci R (2002) Trace-element incorporation in titanite: constraints from experimentally determined solid/liquid partition coefficients. Chem Geol 191:105-119

Tropper P, Manning CE, Essene EJ (2002) The substitution of Al and F in Titanite at high pressure and temperature: experimental constraints on phase relations and solid solution properties. J Petrol 43:17871814

Tulloch AJ (1979) Secondary Ca-Al silicates as low-grade alteration products of granitoid biotite. Contrib Mineral Petrol 69:105-117

Tunheng A, Hirata T (2004) Development of signal smoothing device for precise elemental analysis using laser ablation-ICP-mass spectrometry. J Anal Atom Spectrom 19:932

van Achterbergh E, Ryan CG, Jackson SE, Griffin WL (2001) Data reduction software for LA-ICP-MS. in: Sylvester PJ (ed) laser ablation-ICPMS in the earth sciences: principles and applications. Mineralogical Association of Canada, pp 239-243
Watson EB, Harrison TM (1983) Zircon saturation revisited: temperature and composition effects in a variety of crustal magma types. Earth Planet Sci Lett 64(2):295-304

Watson EB, Liang YA (1995) A simple model for sector zoning in slowly grown crystals: implications for growth rate and lattice diffusion, with emphasis on accessory minerals in crustal rocks. Am Mineral 80:1179-1187

Webster JD, Tappen CM, Mandeville CW (2009) Partitioning behavior of chlorine and fluorine in the system apatite-melt-fluid. II: felsic silicate systems at $200 \mathrm{MPa}$. Geochim Cosmochim Acta 73:559581

Wilamowski A (2002) Chloritization and polytypism of biotite in the Lomnica granite, Karkonosze massif, Sudetes, Poland: stable isotope evidence. Chem Geol 182:529-547

Williams-Jones AE, Migdisov AA, Samson IM (2012) Hydrothermal mobilization of the rare earth elements - a tale of "ceria" and "Yttria". Elements 8(5):355-360

Xie F, Tang J, Lang X, Ma D (2018) The different sources and petrogenesis of Jurassic intrusive rocks in the southern Lhasa subterrane, Tibet: evidence from the trace element compositions of zircon, apatite, and titanite. Lithos 314-315:447-462

Xie L, Wang RC, Chen J, Zhu JC (2010) Mineralogical evidence for magmatic and hydrothermal processes in the Qitianling oxidized tin-bearing granite (Hunan, South China): EMP and (MC)-LAICPMS investigations of three types of titanite. Chem Geol 276: 53-68

Xu LL, Bi XW, Hu RZ, Tang YY, Wang XS, Xu Y (2015) LA-ICP-MS mineral chemistry of titanite and the geological implications for exploration of porphyry cu deposits in the Jinshajiang - red river alkaline igneous belt, SW China. Mineral Petrol 109(2):181-200

Žák J, Verner K, Sláma J, Kachlík V, Chlupáčová M (2013) Multistagemagma emplacement and progressive strain accumulation in the Krkonoše-Jizera plutonic complex, bohemian massif. Tectonics 32:1493-1512

Publisher's note Springer Nature remains neutral with regard to jurisdictional claims in published maps and institutional affiliations. 